\title{
Dynamics of particulate organic matter composition in coastal systems: forcing of spatio-temporal variability at multi-systems scale
}

Liénart Camilla ${ }^{1,{ }^{*}}$, Savoye Nicolas ${ }^{1}$, David Valérie ${ }^{1}$, Ramond Pierre ${ }^{2}$, Rodriguez Tress Paco ${ }^{1}$, Hanquiez Vincent ${ }^{3}$, Marieu Vincent ${ }^{3}$, Aubert Fabien ${ }^{4}$, Aubin Sébastien ${ }^{5}$, Bichon Sabrina ${ }^{1}$,

Boinet Christophe ${ }^{5}$, Bourasseau Line ${ }^{1}$, Bozec Yann ${ }^{6}$, Bréret Martine ${ }^{4}$, Breton Elsa ${ }^{7}$, Caparros Jocelyne ${ }^{8}$, Cariou Thierry ${ }^{9}$, Claquin Pascal ${ }^{10}$, Conan Pascal ${ }^{8}$, Corre Anne-Marie ${ }^{11}$, Costes Laurence ${ }^{1}$, Crouvoisier Muriel ${ }^{7}$, Del Amo Yolanda ${ }^{1}$, Derriennic Hervé ${ }^{3}$, Dindinaud François ${ }^{1}$, Duran Robert ${ }^{12}$, Durozier Maïa ${ }^{11}$, Devesa Jérémy ${ }^{13}$, Ferreira Sophie ${ }^{14}$, Feunteun Eric ${ }^{15}$, Garcia Nicole ${ }^{16}$, Geslin Sandrine ${ }^{5}$, Grossteffan Emilie ${ }^{13}$, Gueux Aurore ${ }^{8}$, Guillaudeau Julien ${ }^{5}$, Guillou Gaël ${ }^{4}$, Jolly Orianne ${ }^{17}$, Lachaussée Nicolas ${ }^{4}$, Lafont Michel ${ }^{16}$, Lagadec Véronique ${ }^{16}{ }^{4}$ Lamoureux Jézabel $^{5}$, Lauga Béatrice ${ }^{12}$, Lebreton Benoît ${ }^{4}$, Lecuyer Eric ${ }^{7}$, Lehodey Jean-Paul ${ }^{17}$, Leroux Cédric ${ }^{9}$, L'Helguen Stéphane ${ }^{13}$, Macé Eric ${ }^{6}$, Maria Eric ${ }^{8}$, Mousseau Laure ${ }^{11}$, Nowaczyk Antoine ${ }^{1}$, Pineau Philippe ${ }^{4}$, Petit Franck ${ }^{11}$, Pujo-Pay Mireille ${ }^{8}$, Raimbault Patrick ${ }^{16}$, Rimmelin-Maury Peggy ${ }^{13}$, Rouaud Vanessa ${ }^{12}$, Sauriau Pierre-Guy ${ }^{4}$, Sultan Emmanuelle ${ }^{5}$, Susperregui Nicolas ${ }^{12,18}$

${ }^{1}$ Univ. Bordeaux, CNRS, UMR 5805 EPOC, Station Marine d'Arcachon, 33120 Arcachon, France

2 Ifremer Centre Bretagne, DYNECO, Z.I. de la Pointe du Diable, 29280 Plouzané, France

${ }^{3}$ Univ. Bordeaux, CNRS, UMR 5805 EPOC, Allée Geoffroy Saint-Hilaire, 33600 Pessac, France

${ }^{4}$ Univ. de la Rochelle, CNRS, UMR 7266 LIENSs, 2 rue Olympe de Gouges, 17000 La Rochelle, France

${ }^{5}$ MNHN, Service des Stations Marines du MNHN, CRESCO, Station Marine de Dinard, 35800 Dinard,

France

${ }^{6}$ Sorbonne Universités, UPMC Univ. Paris 06, CNRS, UMR 7144 AD2M, Station Biologique de Roscoff, 29680 Roscoff, France

${ }^{7}$ Univ. Littoral Côte d'Opale, Univ. Lille, CNRS, UMR 8187 LOG, F-62930 Wimereux, France

${ }^{8}$ Sorbonne Universités, UPMC Univ. Paris 06, CNRS, UMR7621 LOMIC, Observatoire Océanologique,

F-66650 Banyuls sur Mer, France

${ }^{9}$ Sorbonne Universités, UPMC Univ. Paris 06, CNRS, FR2424, Station Biologique de Roscoff, 29680

Roscoff, France

${ }^{10}$ Univ. de Caen-Normandie, UPMC Univ. Paris 06, UMR BOREA, CNRS-7208, IRD-207, Esplanade de la Paix, 14032 Caen, France

${ }_{11}$ Sorbonne Universités, UPMC Univ Paris 06, CNRS, UMR 7093 LOV, Observatoire océanologique, 06230 Villefranche sur mer, France

${ }^{12}$ CNRS/ Univ. Pau \& Pays Adour, Institut Des Sciences Analytiques Et De Physico-Chimie Pour L'environnement Et Les Matériaux - MIRA, UMR 5254, 64000, Pau, France

${ }^{13}$ Univ. de Bretagne Occidentale, CNRS, IRD, IFREMER, UMR 6539 LEMAR, UMS 3113, OSU-IUEM, rue Dumont d'Urville, F-29280 Plouzané, France

${ }^{14}$ Univ. Bordeaux, CNRS, OASU, UMS 2567 POREA, Allée Geoffroy Saint-Hilaire, 33600 Pessac, France

${ }_{15}^{15}$ MNHN, Univ. de Caen-Normandie, UPMC Univ. Paris 06, UMR BOREA, CNRS-7208, IRD-207,

CRESCO-MNHN, Station Marine de Dinard, 35800 Dinard, France 
${ }^{16}$ Aix-Marseille Université, Univ. de Toulon, CNRS, INSU, IRD, UM 110 MIO, 163 Avenue de Luminy, 13288, Marseille, France

${ }^{17}$ Univ. Caen Basse-Normandie, CREC-Station marine, 54 Rue du Dr Charcot, 14530 Luc-sur-Mer, France

${ }^{18}$ Institut des Milieux Aquatiques (IMA), 1 rue de Donzac, 64100 Bayonne, France

\begin{abstract}
:
In costal systems, particulate organic matter (POM) results from a multiplicity of sources having their respective dynamics in terms of production, decomposition, transport and burial. The POM pool experiences thus considerable spatial and temporal variability. In order to better understand this variability, the present study employs statistical multivariate analyses to investigate links between POM composition and environmental forcings for a panel of twelve coastal systems distributed along the three maritime regions of France and monitored weekly to monthly for 1 to 8 years.
\end{abstract}

At multi-system scale, two main gradients of POC composition have been identified: a 'ContinentOcean' gradient associated with hydrodynamics, sedimentary dynamics and depth of the water column, and a gradient of trophic status related to nutrient availability. At local scale, seasonality of POC composition appears to be station-specific but still related to part of the above-mentioned forcings. A typology of systems was established by coupling spatial and temporal variability of POC composition. Four groups were highlighted: 1) the estuarine stations where POC composition is dominated by terrestrial POM and driven by hydrodynamics and sedimentary processes, 2) the oligotrophic systems, characterized by the contribution of diazotrophs due to low nutrient availability, and the marine meso/eutroph systems whose POC composition is 3) either deeply dominated by phytoplankton or 4) dominated by phytoplankton but where the contribution of continental and benthic POC is not negligible and is driven by hydrodynamics, sedimentary processes and the height of the water column.

Finally, the present study provides several insights into the different forcings to POM composition and dynamics in temperate coastal systems at local and multi-system scales. This work also presents a methodological approach that establishes statistical links between forcings and POM composition, helping to gain more objectively insight of forcings.

\title{
Highlights
}

- Three littoral systems, eight embayments and one estuary were studied. POC composition was related to 'Continent-Ocean' and trophic-status gradients. Forcings were (sedimentary) hydrodynamics, water column depth, nutrient availability. At local scale POC composition appears to be station-specific but still related to the above-mentioned forcings. A typology of systems was drawn based on POM composition.

Keywords : particulate organic matter, coastal systems, environmental forcing, meta-analysis, France 


\section{Glossary:}

- Coastal POM = mix of autochthonous POM (in situ pelagic and benthic primary producers) and allochthonous POM (continental POM originating from the continent)

- $\quad$ Continental POM = all POM coming from land (River POM, Anthropogenic POM or Terrestrial POM)

- $\quad$ River POM = freshwater phytoplankton + terrestrial POM

- Terrestrial POM = terrestrial plants debris, litter (the Gironde estuary exhibits two distinct terrestrial POMs: the refractory and the labile terrestrial POM)

- Anthropogenic POM = originating from treated/untreated sewage effluents

- Benthic POM = macrophytes (i.e. macroalgae, spermatophytes), microphytobenthos or even sediment detritus

- Estuarine POM = from the estuarine systems 


\section{Introduction}

Particulate organic matter (POM) in coastal systems includes all living (e.g. phytoplankton) and detrital (e.g. faecal pellets) organic material (Harmelin-Vivien et al., 2008; Volkman and Tanoue, 2002). The organic matter (OM) comes from two categories of sources: 1) autochthonous and 2) allochthonous natural and anthropogenic sources. The first one is mainly primary production that occurs in marine surface waters, nevertheless, due to the shallow depth of coastal systems, benthic primary production (i.e. macrophytes fragments, microphytobenthos) can also be a provider of organic matter in the water column (Malet et al., 2008; Miller et al., 2013; Miller and Page, 2012). The second is imported from the continent, mainly carried by rivers but also by run-off or by artificial outlets. Sources of continental POM are usually considered as river POM, which is a mixture of freshwater phytoplankton and terrestrial POM (e.g. litter, soils), and sometimes anthropogenic inputs such as POM originating from treated/untreated sewage effluents (Berto et al., 2013; Cresson et al., 2012; Liénart et al., 2016). The multiplicity of sources and their respective dynamics in terms of production, decomposition, transport and burial display considerable spatial and temporal variability (Volkman and Tanoue, 2002); it results in differences in their relative contribution to POM pool (Liénart et al., 2017). Such changes may impact biogeochemical cycles and cause variations in the quality of the trophic environment available to consumers (Bănaru et al., 2014; Cresson et al., 2016; Darnaude et al., 2004; Dubois and Colombo, 2014; Dubois et al., 2014).

To cope with the heterogeneous composition of POM, elemental and isotopic ratios of carbon and nitrogen ( $\mathrm{C}: \mathrm{N}, \delta^{13} \mathrm{C}, \delta^{15} \mathrm{~N}$ ) associated with mixing models are commonly used to identify the contribution of each source (i.e. end-member) to the mixture. This method has already been used for various marine or estuarine systems: Venice Lagoon, Italy (Berto et al., 2013); Bay of Marseille, France (Cresson et al., 2012); Kowie River, South Africa (Dalu et al., 2016); Arcachon Lagoon, France (Dubois et al., 2012); Danshuei Estuary, Taiwan (Liu et al., (2007); Bay of Biscay, France (Liénart et al., 2016). However, there is a recognized need to assess how environmental conditions force the composition of POM in order to better understand its variability.

Coastal systems are related to the functioning of the ocean but also of the continent. Thus, they constitute complex and dynamic environments in terms of both nutrient regimes and hydrography (Ostrom et al., 1997). Three environmental forcings are usually considered regarding POM composition. First, primary production is tightly linked with nutrient cycles, temperature and light (Falkowski et al., 1998; Field et al., 1998). Nutrient availability is thus directly affecting phytoplankton production (Chen et al., 2000; Glé et al., 2008). Second, hydrodynamics and sedimentary processes drive river organic matter inputs (Goñi et al., 2009; Higueras et al., 2014; Sanchez-Vidal et al., 2013; Sato et al., 2006). These processes may have a critical effect on river POM (Lebreton et al., 2016; Sanchez-Vidal et al., 2013) but also benthic POM redistribution (Eyre and Ferguson, 2006; Hochard et al., 2012; Zhang et al., 2007). The two previous 
forcings strongly depend on meteorological conditions (e.g. storms, rainfalls, floods). Climate is usually considered a third forcing. However, these forcings are not independent. For example, climatic variations (i.e. rainfalls) may locally control hydrodynamics (i.e. river flows) that is tightly linked with sedimentary processes (i.e. deposition/resuspension). Consequently, changes in these environmental forcings can affect POM composition at different spatial and temporal scales.

To highlight forcings to POM composition, many studies use environmental variables as proxies of forcings. As an example, river flows and salinity are used as proxies of hydrodynamic processes (i.e. indicators of freshwater inputs) and potentially of river OM inputs (Goñi et al., 2009; Lebreton et al., 2016). Also, turbidity or concentration of suspended particulate matter can be used as a proxy of river inputs or resuspension processes that may also limit primary production (e.g. Alpine and Cloern, 1988). A first approach consists in a rough visual-estimation of the relationship between the environmental variables and POM characteristics. In other thematic areas such as ecology or community ecology, statistical approaches are more commonly used. Multivariate analyses are performed to investigate the significance of the relationship between a variable and environmental factors, as for example multiple linear regressions, Principal Component Analyses (PCA), Hierarchical Ascendency Classification (HAC), or Redundancy Analysis (RDA) (David et al., 2012, 2007; Tortajada et al., 2011).

POM composition has been previously quantified by using mixing models based on $\delta^{13} \mathrm{C}, \delta^{15} \mathrm{~N}$ and $\mathrm{C}: \mathrm{N}$ for twelve systems (nineteen stations) distributed along the three French maritime façades (Liénart et al., 2016, Liénart et al., 2017). Over the 12 systems, these studies shows a large spatial variability in POM composition from estuarine systems dominated by terrestrial POM and marine systems dominated by phytoplankton with the occurrence of diazotrophs in Mediterranean systems. Also, at local scale, seasonal variability was observed. Assumptions of the forcings responsible for this spatial and temporal variability were given. Based on these results, the present study investigates how environmental variables force the composition of POM using multivariate analysis (redundancy analysis and regionalization method). This work addresses three questions: 1) what are the different forcings to POM composition at multi-system scale? 2) Are there seasonal patterns of POM composition and what are the forcings to seasonal variability at local scale? 3) Is there a typology of functioning of these systems based on POM composition and its related variations? Finally, spatial and temporal variability are considered over the large gradient of systems considered in this study.

\section{Material and methods}

\subsection{Study sites}


Nineteen stations belonging to twelve systems distributed along the French coastline $\left(42^{\circ} \mathrm{N}-51^{\circ} \mathrm{N}, 4^{\circ} \mathrm{W}-7^{\circ} \mathrm{E}\right.$; Fig. 1) were studied. Four systems are located along the English Channel (the eastern littoral of the English Channel, the Bay of Seine, the Normand-Breton Gulf and the western littoral of the English Channel), one system is located in the Iroise Sea, at the interface between the English Channel and the Atlantic Ocean (the marine end of the Bay of Brest), four systems are located along the Atlantic coast (the Pertuis Charentais Sounds, the Gironde estuary, the Arcachon lagoon and the South-Eastern littoral of the Bay of Biscay) and three systems are located in the Mediterranean Sea (the Bay of Banyuls-sur-mer, the Bay of Marseille and the Bay of Villefranche-sur-mer). Among the twelve systems, four were sampled at two to three stations distributed along a continent-to-ocean gradient (Fig. 1).

The twelve systems are distributed over a latitudinal gradient and exhibit different geomorphological shapes (open coastal systems, bays, lagoon, rias, estuary) and size (surface area ranges from a few to thousands of $\mathrm{km}^{2}$ ). They offer the opportunity to study numerous environmental and ecological gradients of forcings (Table 1) that include the trophic status (from oligo- to eutrophic systems), turbidity (mean suspended particles concentration ranges between milligrams and grams), freshwater influence (mean salinity ranges from 0 to 38), tidal regime (from micro- to megatidal systems) or water column height (from 5 to $80 \mathrm{~m}$ ) and climate (mean winter and summer water temperatures that range from 5 to $12^{\circ} \mathrm{C}$ and from 17 to $28^{\circ} \mathrm{C}$, respectively).

All stations but the South-Eastern littoral of the Bay of Biscay (Tarnos and Biarritz) were weekly to ca. monthly monitored during 3-8 years for physical, chemical, biogeochemical and biological parameters within the scope of the Service d'Observation en Milieu LITtoral (SOMLIT), the French Coastal Monitoring Network (http://somlit.epoc.u-bordeaux1.fr/fr/). The overall aim of the SOMLIT is to assess the long-term evolution of coastal systems and to discriminate climate from local anthropogenic forcings (Goberville et al., 2010). Tarnos and Biarritz stations were monitored ca. monthly to sub-monthly for one year as part of a French regional program (PERMALA-LIGA).

\subsection{Scientific strategy}

The contribution of each source to the POM pool at the nineteen stations was quantified in two previous studies (Liénart et al., 2016; Liénart et al., 2017). The possible organic matter sources contributing to coastal POM composition considered in these articles were phytoplankton, diazotrophs, river POM (freshwater phytoplankton + terrestrial POM), anthropogenic POM and/or benthic POM (macrophytes + microphytobenthos). Freshwater phytoplankton and terrestrial POM were considered as two distinct sources in the Gironde estuary only.

For all systems, forcings to the coastal POM composition were identified and environmental variables were selected as proxies to represent 
ACCEPTED MANUSCRIPT

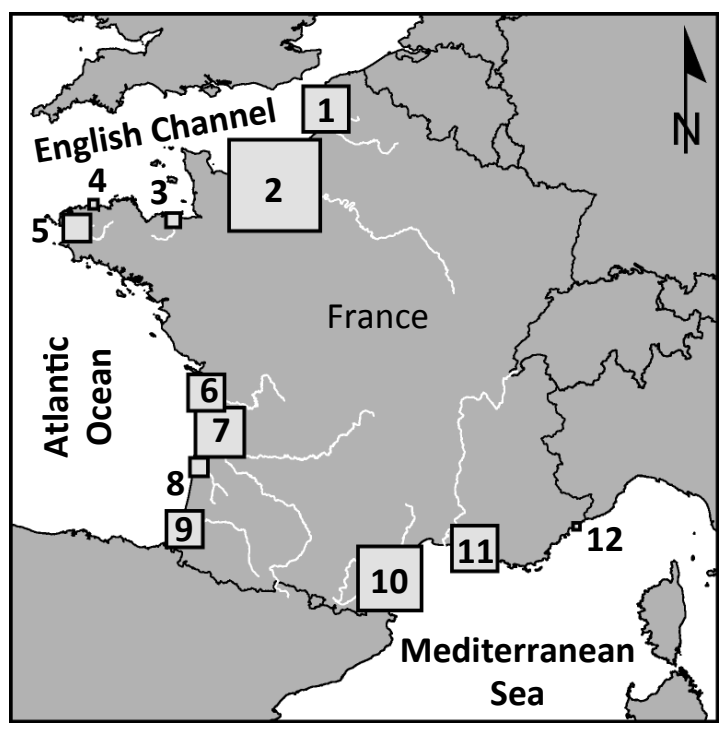

Figure 1: Location of the studied systems (in insets numbered from 1 to 12 on the upper left pannel) and stations (black circles. 1. Eastern English Channel, 2. Bay of Seine, 3. Normano-Breton Gulf, 4. Western English Channel, 5. Bay of Brest, 6. Charentais Sounds, 7. Gironde Estuary, 8. Arcachon Lagoon, 9. South-East of the Bay of Biscay, 10. Bay of Banyuls, 11. Bay of Marseille, 12. Bay of Villefranche. Rivers are represented in

white.
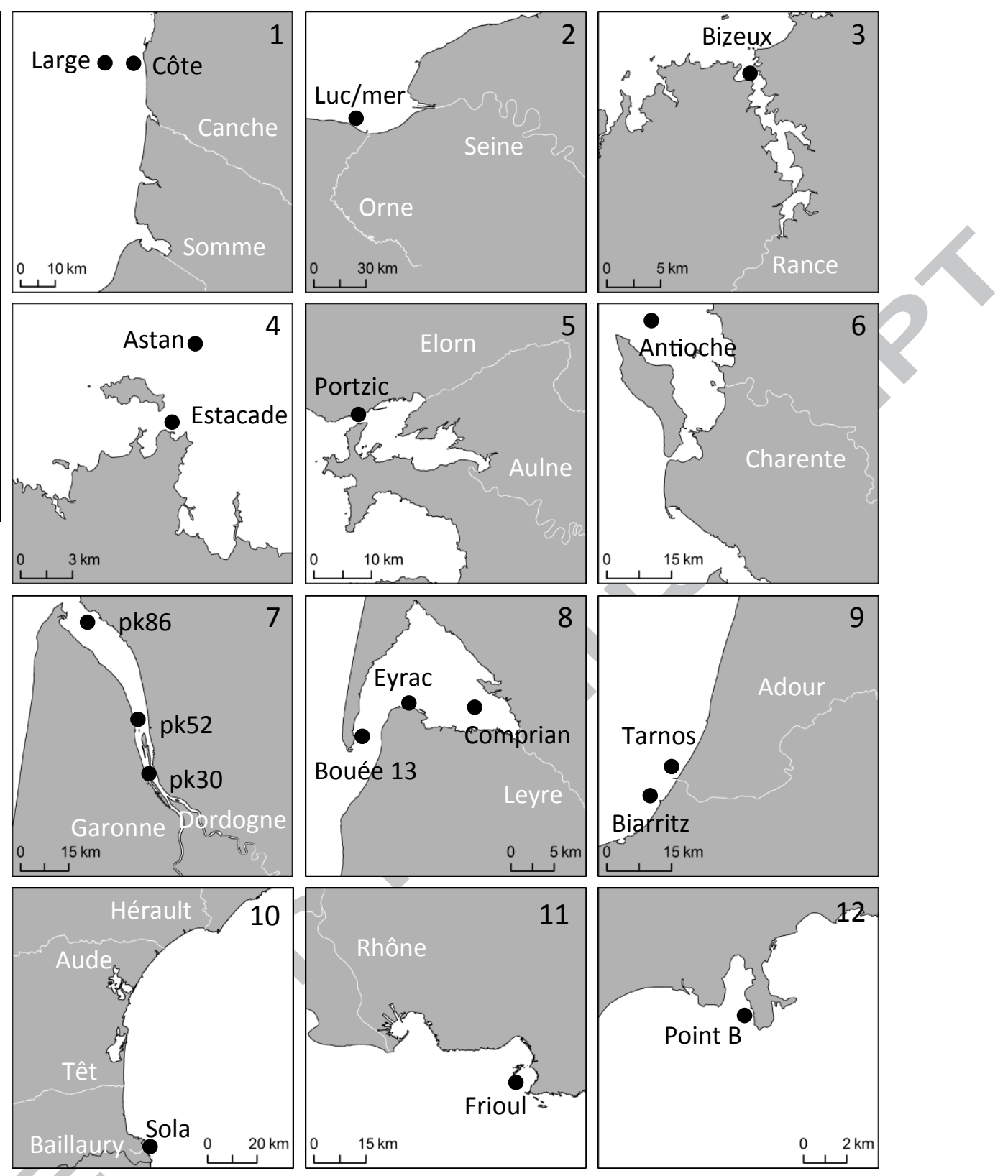
ACCEPTED MANUSCRIPT

\begin{tabular}{|c|c|c|c|c|c|c|c|c|c|c|}
\hline & System & Type of system & Stations & $\begin{array}{l}\text { Depth at the } \\
\text { sampling } \\
\text { station }(\mathrm{m})\end{array}$ & Study period & $\begin{array}{l}\text { Sampling } \\
\text { frequency }\end{array}$ & Tidal range & $\begin{array}{l}\text { Tidal range } \\
\text { (m) }\end{array}$ & Considered rivers & Annual flow rates $\left(\mathrm{m}^{3} \cdot \mathrm{s}^{-1}\right)$ \\
\hline \multirow{4}{*}{ 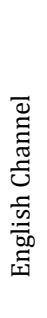 } & Easter English Channel & littoral system & Côte, Large & $21 ; 50$ & $2010-2014$ & bi-monthly & macrotidal & 7.7 & Somme, Canche & $35 ; 12$ \\
\hline & Bay of Seine & open bay & Luc/mer & 5 & 2009-2013 & bi-monthly & macrotidal & 6.6 & Seine, Orne & $486 ; 22$ \\
\hline & Normano-Breton Gulf & ria semi-fermée & Bizeux & 25 & $2012-2014$ & bi-monthly & megatidal & 14 & Rance & 1.7 \\
\hline & Western English Channel & littoral system & Estacade, Astan & $11 ; 60$ & 2009-2014 & bi-monthly & macrotidal & 7.5 & - & - \\
\hline \multirow{4}{*}{ 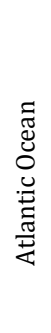 } & Bay of Brest & semi-enclosed ria & Portzic & 10 & 2008-2014 & weekly & macrotidal & 7.6 & Aulne, Elorn & $24 ; 6.1$ \\
\hline & Charentais Sounds & semi-enclosed sound & Antioche & 40 & $2011-2014$ & bi-monthly & macrotidal & 6.5 & Charente, Gironde & $100 ; 764$ \\
\hline & Gironde Estuary & estuary & pk30, pk52, pk86 & $8 ; 7 ; 8$ & $2007-2014$ & ca. monthly & macrotidal & 5 & Gironde & 764 \\
\hline & Arcachon Lagoon & semi-enclosed lagoon & $\begin{array}{c}\text { Comprian, Eyrac, } \\
\text { Bouée13 }\end{array}$ & $6 ; 8 ; 25$ & 2009-2014 & bi-monthly & mesotidal & 4.2 & Leyre & 17 \\
\hline \multirow{4}{*}{ 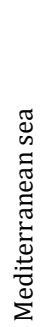 } & $\begin{array}{l}\text { South-East of the Bay of } \\
\text { Biscay }\end{array}$ & littoral system & Tarnos, Biarritz & $30 ; 30$ & $\begin{array}{l}\text { june } 2013 \\
\text { june } 2014\end{array}$ & $\begin{array}{l}\text { monthy to } \\
\text { bi-weekly }\end{array}$ & mesotidal & 2.6 & Adour & 480 \\
\hline & Bay of Banyuls & open bay & Sola & 27 & $2010-2014$ & bi-monthly & microtidal & centimetric & $\begin{array}{l}\text { Têt, Rhône, Aude, } \\
\text { Hérault, Baillaury }\end{array}$ & $\begin{array}{l}8.6 ; 1619 ; 31 ; 34 ; \\
\text { mediterranean oued }\end{array}$ \\
\hline & Bay of Marseille & open bay & Frioul & 60 & 2009-2014 & bi-monthly & microtidal & centimetric & Rhône & 1619 \\
\hline & Bay of Villefranche & semi-enclosed bay & PointB & 80 & $2010-2013$ & weekly & microtidal & centimetric & Paillon & - \\
\hline
\end{tabular}

Table 1: Characteristics of the twelve studied systems. Annual flow rates (average per river) of the considered rivers for each systems. Water temp.: Water temperature (min-max for each system), i_sal: salinity index (see 2.4.1 for calculation; mean value for each station), salinity, suspended particles, nitrates, ammonium, phosphates and chlorophyll $a$ (average min - average max for each system), particulate organic matter, POC:Chl $a$ : particulate organic carbon to chlorophyll a ratio (mean value for each station), \% SOC: soil organic carbon percentage (calculated for each system from Askoy et al., 2016). All values are measured over the studied period for each station. 
ACCEPTED MANUSCRIPT

\begin{tabular}{|c|c|c|c|c|c|c|c|c|c|c|c|c|c|}
\hline & Stations & Trophic status & $\begin{array}{l}\text { Water temp. } \\
\quad\left({ }^{\circ} \mathrm{C}\right)\end{array}$ & Salinity & i_sal & $\begin{array}{l}\text { Suspended } \\
\text { particles } \\
\left(\mathrm{mg} \cdot \mathrm{L}^{-1}\right)\end{array}$ & $\begin{array}{c}\text { Nitrate in } \\
\text { winter }(\mu \mathrm{M})\end{array}$ & $\begin{array}{l}\text { Ammonium } \\
(\mu \mathrm{g} . \mathrm{L}-1)\end{array}$ & $\begin{array}{l}\text { Phosphates } \\
\text { ( } \mu \mathrm{g} . \mathrm{L}-1)\end{array}$ & $\begin{array}{c}\text { Chlorophyll } a \\
\left(\mu \mathrm{g} \cdot \mathrm{L}^{-1}\right)\end{array}$ & $\begin{array}{c}\text { Particulate } \\
\text { organic carbon }\end{array}$ & POC:Chl $a$ & $\%$ SOC \\
\hline \multirow{4}{*}{ 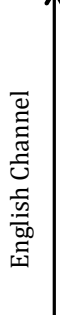 } & Côte, Large & eutrophic & $5-20$ & $33-35$ & $0.964-0.980$ & $0.5-5$ & $5-30$ & $0-4$ & $0-1.5$ & $0.5-10$ & $312 ; 205$ & $119 ; 158$ & 1.8 \\
\hline & Luc/mer & eutrophic & $5-20$ & $30-34$ & 0.915 & $1-100$ & $30-45$ & $0.05-7$ & $0-2$ & $0.3-15$ & 633 & 280 & 2.8 \\
\hline & Bizeux & mesotrophic & $8-19$ & $33-35$ & 0.972 & $0.4-20$ & $\approx 30$ & $0.01-2$ & $0-0.7$ & $0.3-5$ & 220 & 194 & 2.0 \\
\hline & Estacade, Astan & mesotrophic & $8-17$ & $34.5-35.5$ & $0.991-0.992$ & $0.2-13$ & $9-12$ & $0.05-1$ & $0.05-0.5$ & $0.2-4$ & $115 ; 112$ & $220 ; 175$ & 3.8 \\
\hline \multirow{5}{*}{ 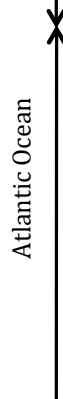 } & Portzic & mesotrophic & $8-18$ & $33-35.5$ & 0.975 & $0.2-20$ & $20-30$ & $0.1-2$ & $0-0.5$ & $0.2-6$ & 175 & 269 & 4.6 \\
\hline & Antioche & mesotrophic & $6-21$ & $30-35$ & 0.950 & $1-15$ & $20-25$ & - & $0-0.7$ & $0.2-5$ & 248 & 184 & 3.7 \\
\hline & pk30, pk52, pk86 & eutrophic & $5-25$ & $0-31.5$ & $0.024-0.724$ & $5-1000$ & $60-200$ & $0-6$ & $0-10$ & $0.3-10$ & $800-8000$ & $750-4800$ & 3.9 \\
\hline & $\begin{array}{l}\text { Comprian, Eyrac, } \\
\text { Bouée13 }\end{array}$ & mesotrophic & $5-25$ & $20-35.5$ & $0.880-0.915-0.968$ & $0.3-20$ & $7-50$ & $0.05-15$ & $0.01-1.5$ & $0.1-7$ & $325 ; 323 ; 362$ & $\begin{array}{c}268 ; 241 ; \\
291\end{array}$ & 8.2 \\
\hline & Tarnos, Biarritz & mesotrophic & $11-23$ & $31-35$ & $0.838-0.775$ & $0.2-20$ & $10-25$ & $0.08-5$ & $0.06-1.4$ & $0.2-5$ & $279 ; 255$ & $217 ; 280$ & 3.2 \\
\hline \multirow{3}{*}{ 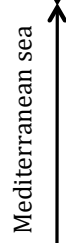 } & Sola & $\begin{array}{c}\text { weakly } \\
\text { oligotrophic }\end{array}$ & $8-25$ & $34-38.5$ & 0.981 & $0.1-7$ & $2-6$ & $0.005-0.8$ & $0-0.3$ & $0.05-4$ & 109 & 382 & 4.3 \\
\hline & Frioul & oligotrophic & $12-26$ & $34.5-38.5$ & 0.989 & $0.1-5$ & $0-6$ & $0.005-2$ & $0-0.2$ & $0-3$ & 63 & 200 & 4.4 \\
\hline & PointB & oligotrophic & $12.5-28$ & $36.8-38.5$ & 0.988 & $0.5-40$ & $0.5-4$ & $0-0.3$ & $0-0.3$ & $0.05-2.5$ & 118 & 610 & 2.6 \\
\hline
\end{tabular}

Table 1 (part 2) 
variability in the processes (Table 1). The selected forcings were divided in two categories; the 'variant forcings' that vary seasonally over the annual cycle (e.g. nutrient concentrations, river flow, temperature) and the 'invariant forcings' that do not vary over time (e.g. depth of the station, latitude). Redundancy of variables has been minimized by previous examinations of between-variables correlations (stepwise regression; Brocard, Gillet and Legendre, 2011).

Proxies of variant environmental forcings selected for our analysis were: salinity, river flow, water temperature, nutrients (ammonium, nitrates, phosphates), suspended particulate matter (SPM) and the POC:Chla ratio. Salinity and river flow were used as proxies of river hydrodynamic processes driving freshwater and river/terrestrial POM inputs. Water temperature and nutrients availability have been identified as controlling factors of primary production (Chen et al., 2000; Cloern, 1996; Phlips et al., 2002). Thus, ammonium $\left(\mathrm{NH}_{4}^{+}\right)$, nitrates $\left(\mathrm{NO}_{3}^{-}\right)$and phosphates $\left(\mathrm{PO}_{4}{ }^{-}\right)$were considered in the present study. Silicates were not selected because of their strong correlation with nitrates. Also, nutrients can be a sign of freshwater inputs or remineralization processes (Dodds, 1993). Water temperature was also used as a proxy of meteorological conditions as it follows seasonal variations. In coastal systems, suspended particulate matter (SPM) is a proxy of sedimentary dynamics. Finally, the POC:Chla ratio indicates whether it is an input of degraded (e.g. terrestrial) versus non-degraded (i.e. phytoplankton) OM.

Because a single variable can be a proxy of several processes, combining variables allows for identifying which processes are influencing the POM composition. For example, SPM concentrations can indicate either the resuspension of benthic material or a contribution of particles from rivers in the systems subject to these two sources. Otherwise, SPM is an indicator of phytoplankton. Therefore, source discrimination is done according to the POC:Chla ratio which is an ubiquitous variable. Depending on its value, the POC:Chla ratio indicates the contribution in 'alive' or non-degraded phytoplankton $\left(<200{\left.\mathrm{~g} . \mathrm{g}^{-1}\right)}\right.$ or degraded material from resuspension or river inputs $\left(>200\right.$ g.g $^{-1}$ ) (Savoye et al., 2003 and references therein). Similarly, nutrient concentrations may be a proxy of river inputs when associated with river flows.

As invariant forcings, latitude was used as a proxy of local climate. The depth of the water column was used as a proxy of the distance between surface water and benthic POM source (i.e. the sediment). Similarly, the distance to the river mouth was also considered as a proxy of the distance to river POM source. Finally, the percentage of organic carbon in the watershed soil (\% SOC) was considered as it may partly drive the quantity of terrestrial POM that is exported to the study stations.

\subsection{Data bases}

POM compositions at the nineteen stations were quantified in two previous articles; one about the South-Eastern littoral of the Bay of Biscay (Tarnos and Biarritz stations; (Liénart et al., 2016)) and the second investigating the seventeen SOMLIT stations 
(Liénart et al., 2017). Temperature, salinity, nutrients, SPM, POC and Chllorophyll $a$ concentrations, depth of the station and latitude were downloaded from the SOMLIT website (http://somlit.epoc.u-bordeaux1.fr/fr/) for all stations except the two of the South-Eastern littoral of the Bay of Biscay that were independently monitored by a regional program. River flows were obtained from BanqueHydro (http://www.hydro.eaufrance.fr/) and Agence de l'Eau Rhône-Méditerrannée-Corse. Data of percentages of soil organic carbon were obtained from Aksoy et al. (2016).

\subsection{Data treatment and statistical analyses}

POM composition was calculated in terms of carbon concentration ( $\mu \mathrm{g} . \mathrm{L}^{-1}$ ) by multiplying the date to date relative contributions of each source, quantified in Liénart et al. (2016) and Liénart et al. (2017), by the particulate organic carbon (POC) concentrations ( $\left.\mu \mathrm{g} \cdot \mathrm{L}^{-1}\right)$.

POM composition expressed in $\mu \mathrm{g} \cdot \mathrm{L}^{-1}$ was used for the statistical analyses performed on each station independently (i.e. seasonality index, see 2.4 .2 and local scale RDAs, see 2.4.3). It was also used for the statistical analyses performed at the scale of the nineteen stations (i.e. multi-systems RDAs, see 2.4.3 and regionalization method, see 2.4.4). Nevertheless relative POM composition (expressed \%) was also used for the statistical analyses performed at the multi-system scale for a better comparison of the contribution of a given source to the POM pool among the nineteen stations.

Statistical analyses were performed with the R software (http://cran.r-project.org/, $\mathrm{R}$ development core team 2009).

\subsubsection{Pre-treatment of environmental data}

Environmental variables used as proxies of forcings were pre-treated as described below 1) to better integrate seasonal variability over the sampling period for local-scale analyses and 2) to homogenise the inter-systems variability for multi-system scale analyses.

River flows $\left(\mathrm{Q} ; \mathrm{m}^{3} \cdot \mathrm{s}^{-1}\right)$ were integrated over the 14 days preceding the sampling date of coastal POM, i.e. over the mean time lapse between two samplings. When more than one tributary was considered for a given system, river flows values were weighted by the distance to river mouth (QRiverw; Eq. (1)).

$\mathrm{Q}_{\text {RiverW }}=\left(\left(\mathrm{Q}_{\text {river1 }} / \mathrm{D}_{\text {river1 }}\right)+\left(\mathrm{Q}_{\text {river2 }} / \mathrm{D}_{\text {river2 }}\right)\right) /\left(\mathrm{D}_{\text {river1 }}+\mathrm{D}_{\text {river2 }}\right)$

Where $\mathrm{Q}$ is the river flow $\left(\mathrm{m}^{3} \cdot \mathrm{s}^{-1}\right)$ and $\mathrm{D}$ is the distance from the river mouth to the sampling station $(\mathrm{km})$.

To avoid artificial discrimination in statistical analysis based on salinity disparities between Mediterranean (38 mean annual value) vs English Channel and Atlantic Ocean (34 mean annual value) systems, a salinity index (i_sal; Table 1) was defined as following: the mean salinity value of each station was divided by the maximal value of 
the respective maritime region (38.4 for Mediterranean stations, 35.5 for English Channel and Atlantic Ocean stations). This index ranges between 0 for pure freshwater and 1 for pure marine water.

\subsubsection{Seasonality}

The coefficient of determination $\left(\mathrm{R}^{2}\right)$ for the best fit between the data and a sinusoidal model was calculated and used as an index of seasonality in order to identify and compare seasonal patterns in the contribution of each organic matter source at each station. The higher is the $\mathrm{R}^{2}$, the greater is the seasonality of the given source. Monthly mean concentrations (annual mean cycle) were computed for each source and station. Missing monthly data were extrapolated from previous and following months.

Sinusoidal models (Eq. (2)) were fit to the annual mean cycle using a least-squares non-linear regression ('nlsLM' (Nonlinear Least Squares) function of the \{minpack.lm\} 1.2-0 version package).

$\mathrm{S}=a \cdot \sin (2 \pi / T \cdot t+d)+b$

Where $\mathrm{S}$ is the contribution of OM source, $a$ is the half-amplitude, $T$ the period (12 or 6 months), $t$ the time, $d$ the shift of the model compared to the y-axis and $b$ the average.

The period used for the models was a 12 or 6 month period because usually, seasonal variations occur over an annual or semi-annual cycle (12-month or 6-month period, respectively). As an example, phytoplankton blooms typically occur every year in spring. However, periods can be shifted in time and the 6-month period may be more representative to describe the process. Also, some processes may happen on a 6-month period. The increase of river flows may occur in spring during snow melting upstream or in autumn during strong rainfall events.

The coefficient of determination $\left(\mathrm{R}^{2}\right)$ was calculated by repeating the following protocol for each source contribution and station: A first sinusoidal model was fitted on data with a 12 or 6 month period (T). 1) If the total model or half-amplitude $(a)$ of the equation were not significant ( $p$-value $>0.05$ ) then the source was not characterized by a seasonal cycle and the $\mathrm{R}^{2}$ of this model was selected. 2) If the total model and halfamplitude $(a)$ of the equation were significant ( $p$-value $<0.05$ ), then a second sinusoidal model was fitted on residuals from the first model with a 6 or 12 month period (T) according to the first model. 2.1) If the half-amplitude $(a)$ of the second model was not significant, then seasonality was modelled by a one-sinus equation and the $\mathrm{R}^{2}$ from the first model was selected. 2.2) If the half-amplitude ( $a$ ) of the second model was significant, both sinusoidal equations were summed to form a two-sinus equation model. The p-value of the two-sinus model must be significant to select this $\mathrm{R}^{2}$ as the seasonal index.

\subsubsection{Forcings at local and multi-system scales}


To determine forcing variables that drive POC composition, a constrained form of linear ordination was used: the Redundancy Analysis (RDA) ('dudi.pca' and 'pcaiv' function of the \{ade4\} 1.7-2 version package). This analysis summarizes multiple linear regressions between components of response variables (in this case POM composition) that are explained by a set of explanatory variables (in this case environmental variables). A matrix of the fitted values of all response variables generated through multiple linear regressions is then subject to principal component analysis. RDA can be considered as a constrained version of principal components analysis (PCA), wherein canonical axes - built from linear combinations of response variables - must also be linear combinations of the explanatory variables (i.e. fitted by multi-linear regression). The RDA generates one ordination in the space defined by the matrix of response variables and another in the space defined by the matrix of explanatory variables. Residuals generated by the multi-linear regression step, which yield non-canonical axes, may also be ordinated. Detailed information is available in Legendre and Legendre (1998).

RDAs were performed at two scales: 1) At a multi-system scale including for all stations mean annual values integrated over time of source contribution, variant and invariant forcings. Multi-system RDAs were performed four times, on concentrations and proportions of sources both with and without considering the Gironde estuary; 2) At a local scale including for a given station, date to date source concentration data and variant forcings. The two upstream stations of the Gironde estuary (pk30 and pk52) were grouped in a single RDA as their compositions were similar, and the downstream station (pk86) was treated separately.

\subsubsection{Typology of systems}

In order to achieve a typology of stations based on their POM composition, a regionalization method adapted from Souissi et al. (2000) was performed. This method, based on multivariate cluster analysis (Fig. 2), is valuable for integrating spatial variability and also seasonal variations specific to each site. The robustness of the regionalization method has already been demonstrated in previous studies in the field of marine ecology (Modéran et al., 2010; Tortajada et al., 2011).

The analysis was performed on a contingency matrix (stations, sources, months) computed from average monthly values of sources. For each month, a dendrogram was performed with 10 cut-off levels considered. Then, for each cut-off level, similarities between stations were identified within the 12 monthly dendrograms. At last, global similarities between stations were computed by a fuzzy clustering technique that returns probabilities of membership for each station in each cluster. 


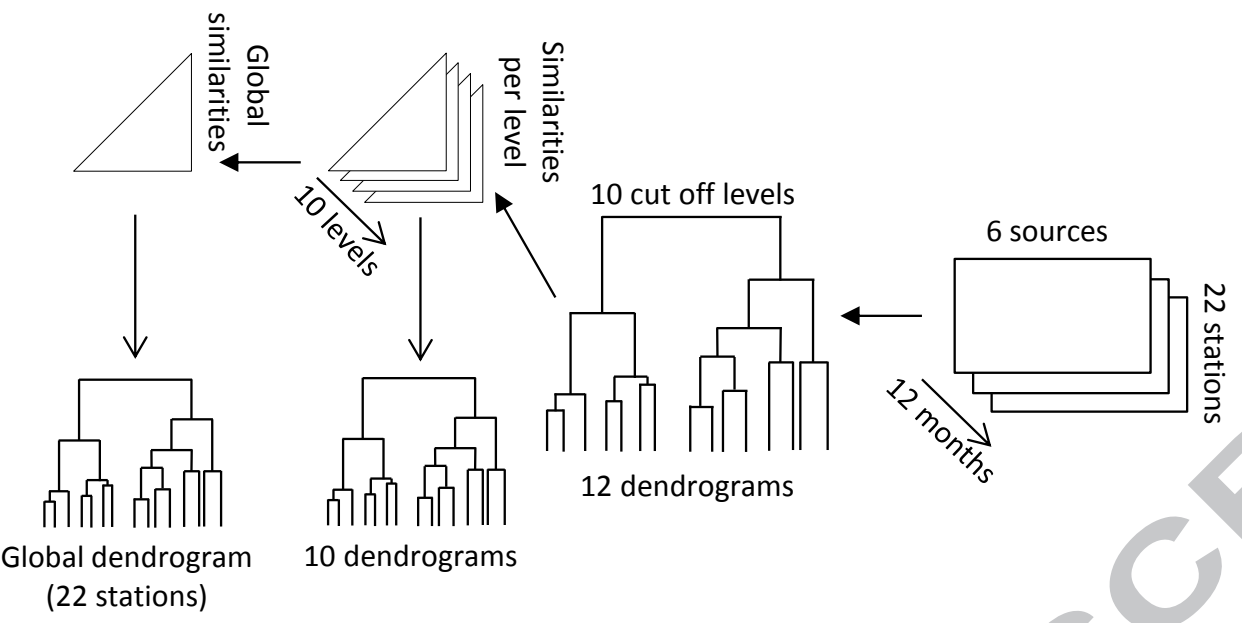

Figure 2: Summary diagram of the steps of the regionalization method (from Souissi et al., 2000) from contingency tables (station $x$ sources) of each month to the final global cluster.

\section{Results}

\subsection{Annual POC concentrations and composition}

Mean annual concentrations of particulate organic carbon (POC) ranges from ca. 60 to $600 \mu \mathrm{g} . \mathrm{L}^{-1}$ for overall marine stations and from ca. 800 to $8000 \mu \mathrm{g} . \mathrm{L}^{-1}$ for the Gironde estuary (Fig. 3). Lower values are found for Mediterranean Sea marine stations where POC concentrations ranges from ca. 60 to $115 \mu \mathrm{g} \cdot \mathrm{L}^{-1}$.

Overall, the POM pool of the coastal systems is highly dominated by phytoplankton, with the exception of the Gironde estuary (Fig. 3). Indeed, in this system, POM is composed of an average of $93 \%$ terrestrial material and only $7 \%$ phytoplankton. The coastal POM of the other studied systems (i.e. marine systems) is largely dominated by phytoplankton ( $84 \%$ on average). Depending on station, river POM contribution varies from $0 \%$ (Astan, Estacade) to $20 \%$ (Biarritz), benthic POM contribution (i.e. macrophytes and microphytobenthos) from 0\% (Côte, Large, Antioche, Bouée13 and Mediterranean stations) to $19 \%$ (Comprian), diazotrophs contribution from $10 \%$ to $17 \%$ in the Mediterranean stations, and anthropogenic POM contribution from 5\% (Biarritz) to 6\% (Frioul). 


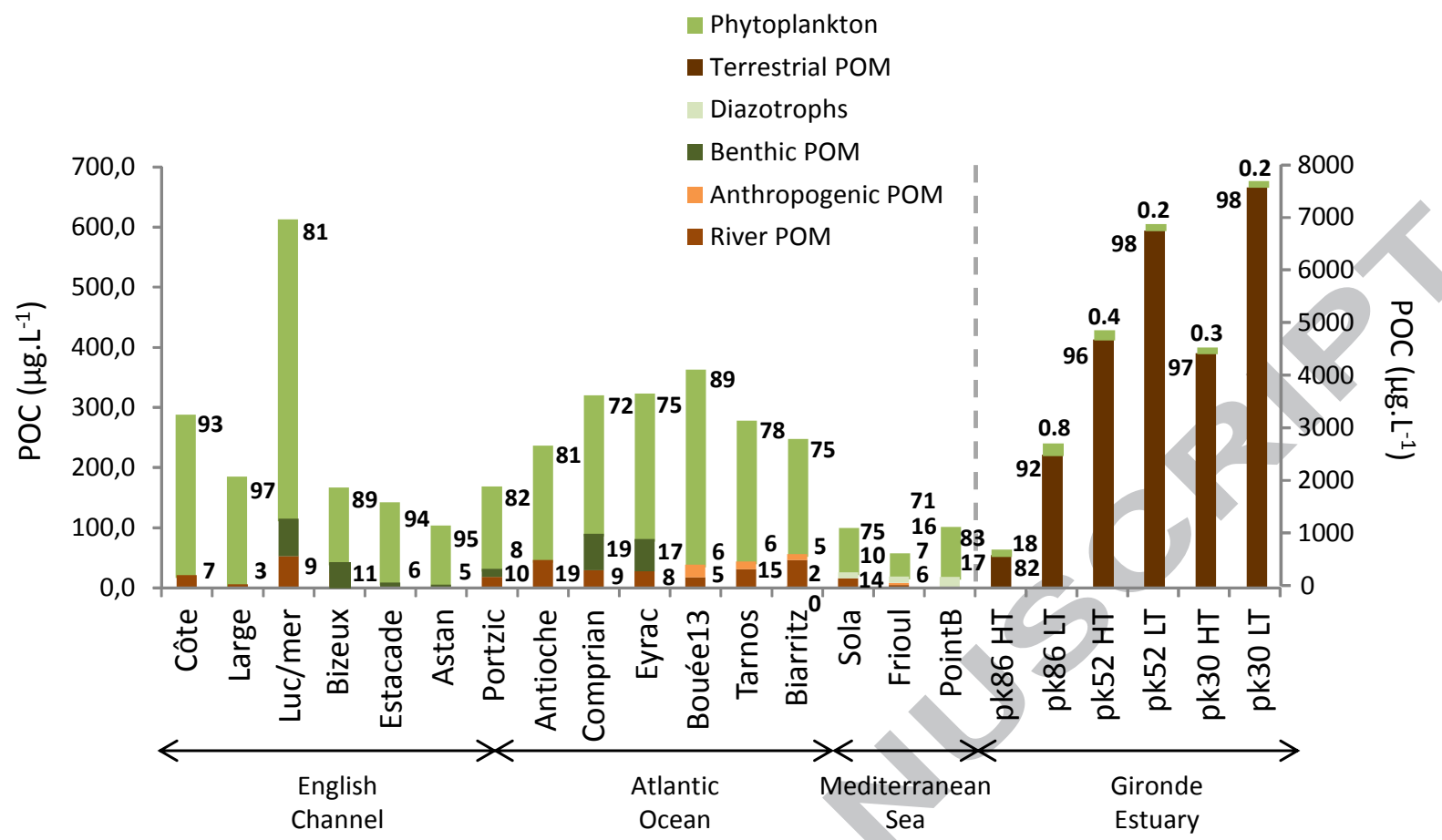

Figure 3: Composition of particulate organic carbon (mean annual values integrated over time). Values associated to the histograms are proportions (\%) of each source (see. Liénart et al., 2017). The Gironde estuary refers to the right axis; the other stations refer to the left axis. HT : high tide; LT : low tide.

\subsection{Seasonal variability of POC composition}

Seasonality was investigated for each station and source over the mean annual cycle and similar seasonal pattern of POC concentrations are observed for most of the sources (Fig. 4, A, B and C).

Within the Gironde estuary, terrestrial POC exhibits a maximum concentration in autumn/winter (from October/November to February/March; e.g. pk52LT and pk30LT) (Fig. 4). Phytoplankton seasonal pattern is different for pk86 and the two other stations. At pk86 (HT and LT), maximum phytoplankton POC concentration appears in winter (February/March) and summer (May to July/August). At pk52 and pk30 (HT an LT) maximum phytoplankton POC concentration also appears in winter (February/March) but the summer maximum is much smaller or even absent (Fig. 4).

For the marine systems, depending on the station, maximum phytoplankton POC concentration appears in late winter (e.g. Luc/mer, Bouée13), in spring (e.g. Bizeux, Portzic, Sola) and/or in summer (e.g. Antioche Eyrac) (Fig. 4). Some stations also show an additional peak in autumn (PointB, Sola). Seasonal variations in diazotrophs POC concentration are specific to each station. Sola and Frioul exhibit a maximum concentration in late winter early spring whereas for PointB it is in summer. Also, Frioul shows a second peak in late summer/early autumn. River POC concentration is for most of stations higher during winter (from October/November to March/April; e.g. Portzic, 
Antioche, Bouée13). Sometimes, the maximum is shifted to late autumn or early spring (Frioul, Large). Some stations exhibit a second peak in summer (Comprian, Biarritz, Sola) but two of them have their maximum river POC concentration during this period (Côte, Eyrac). Benthic POC concentration is highest in autumn/winter, but few stations also exhibit noticeable peaks in spring or summer (Bizeux, Portzic) or small ones in spring (Comprian, Eyrac). Finally, anthropogenic source exhibits no seasonal pattern except at Frioul where the maximum concentration appears in late winter.
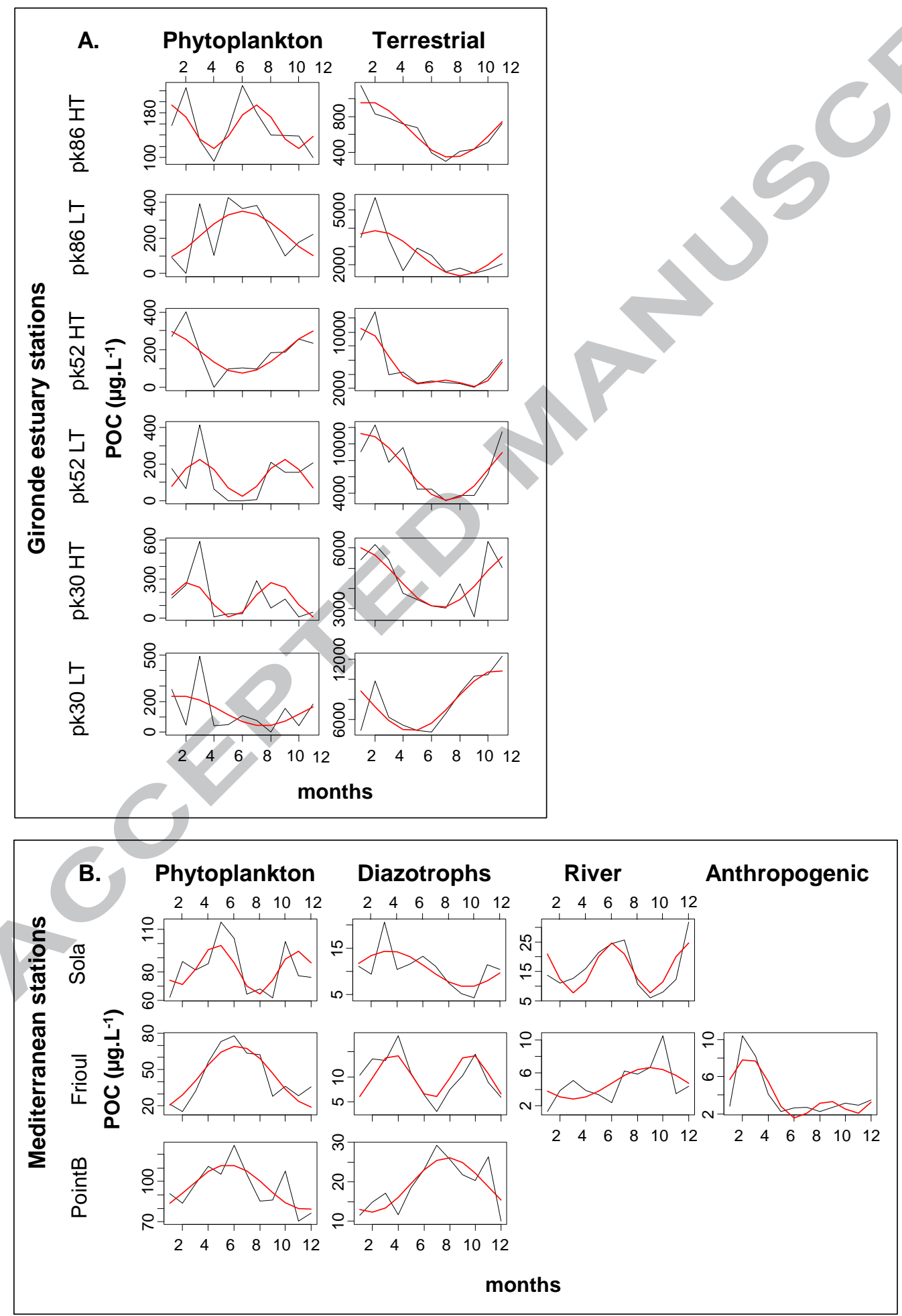


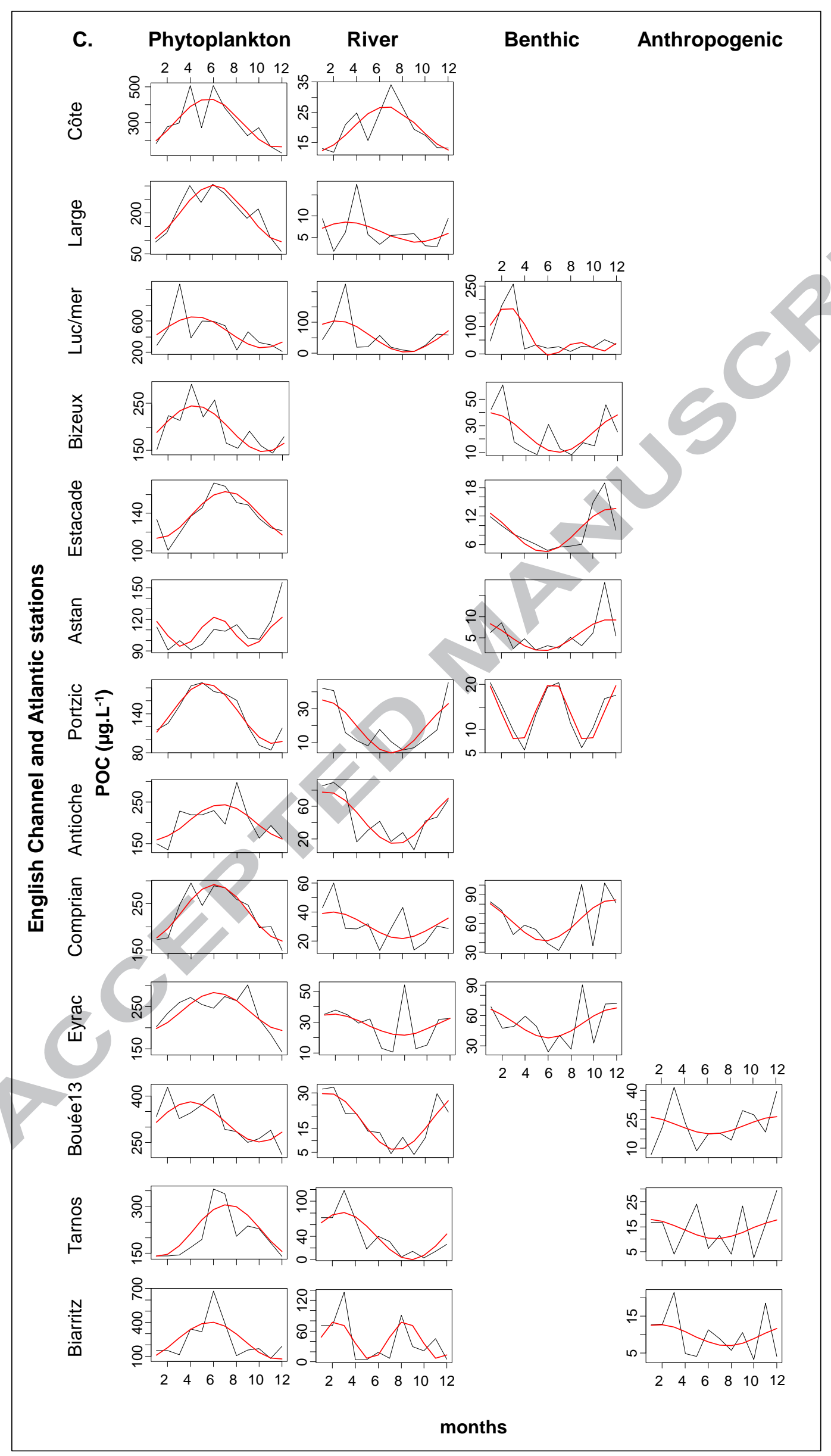


Figure 4: Mean annual cycle of POC concentration of each source. Black lines: monthly averages over the studied periods. Red lines: sinusoidal model (see 2.4.2). Scales of Y-axis are different for each source and station. A. Gironde estuary stations, B. Mediterranean stations, C. English Channel and Atlantic stations.

The index of seasonality $\left(\mathrm{R}^{2}\right)$ was computed for each source and each station (Fig. 5). For each maritime façade, the average index of seasonality (Fig. 5) ranges between 0.46 for the Atlantic façade and 0.59 for Mediterranean Sea. However, all façades exhibit a large variability of the $\mathrm{R}^{2}$ between stations (e.g. from 0.33 to 0.60 for the Atlantic façade). Some stations reveal a very seasonal pattern for almost all sources $(>0.60$ for Portzic, Estacade and pk52HT) whereas other show no or low seasonality $(<0.40$ for Eyrac and Biarritz). Seasonality is more station-specific than façade-specific. Considering the different sources, the index of seasonality is high for the pelagic primary producers (phytoplankton and diazotrophs, 0.63 and 0.57 respectively) in marine systems as well as for terrestrial source in the Gironde estuary (0.72). Benthic and river POM sources have similar values of the index of seasonality ( 0.52 and 0.49 respectively). No seasonal patterns appear for anthropogenic source that is characterized by a low index of seasonality (0.26) except in Frioul. Significance of the $\mathrm{R}^{2}$ is usually the best for sources and stations exhibiting a high index of seasonality.

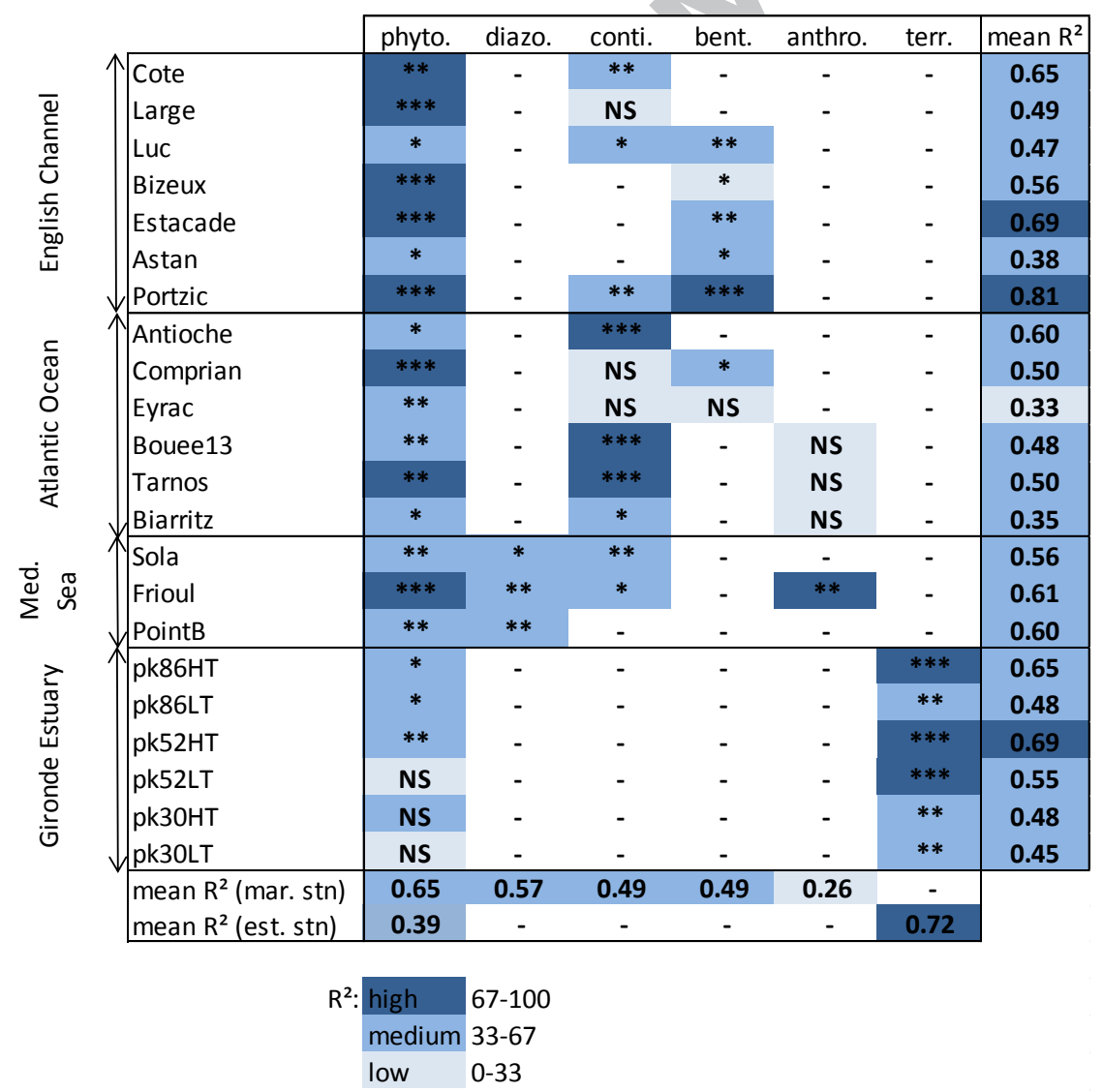

Figure 5: Coefficient of determination $\left(\mathrm{R}^{2}\right)$ of the best fit between the mean annual cycle and the sinusoidal model, for each station and each source. The gradient of blue color illustrates 
the $\mathrm{R}^{2}$ value. '*', '**', '***'; significant fit between the model and data (p-value<0.05, <0.01, $<0.001$ ), 'ns': non significant fit between model and data, Med.: Mediterranean, phyto.: phytoplankton, diazo.: diazotrophs, river.: river POC, benthic: benthic POC, anthro.: anthropogenic POC, terr.: terrestrial POC. mar. stn.: marine stations, est. stn.: estuarine stations.

\section{Discussion}

\subsection{Large scale forcing: a multi-system overview}

Redundancy Analyses (RDA) have been performed including all stations (mean annual values) in order to determine which forcings may explain the contribution of each source to the POM composition. The analyses have been performed on both concentration (Fig. 6, A and C) and proportion (Fig. 6, B and D) of POM sources. For each dataset, two RDA have been performed including (Fig. 6, A and B) and without including the Gironde estuary (Fig. 6, C and D). The three stations of the Gironde estuary have been considered for high and low tides separately. The comparison between projections of the sources and forcing variables revealed two gradients of POC depending on the data sets: 1) a 'Continent-Ocean' gradient of POC, 2) a gradient of trophic status.

The gradient of 'Continent-Ocean' POC is represented on axis1 of the two RDAs that includes the estuarine stations (Fig. 6, A and B). It opposes the stations of the Gironde estuary, characterized by a large amount/proportion of terrestrial POC and the other marine stations where POC is largely composed of phytoplankton. On Fig. 6A, an upstream-downstream gradient of estuarine stations can be observed on axis1: station located at the mouth of the estuary (pk86 at high tide) being closer to marine stations. About $65 \%$ of the projection of the sources is explained by environmental variables on the two RDAs. Associated to this first gradient, high POC:Chla ratio, high SPM and nutrient concentrations and low salinities characterize the estuarine stations. In contrast, marine stations are associated with high salinities and low POC:Chla ratio reflecting the major contribution of phytoplankton to $\mathrm{POM}$ composition in marine waters. According to our knowledge, no study compares forcings of POM composition of estuarine versus marine systems. However estuaries provide a gradient of terrestrial contribution allowing the comparison of river and marine ends. More generally, estuaries subject to strong tidal forcing are characterized by high SPM concentrations and a long term accumulation of particles (Middelburg and Herman, 2007) leading to turbidity maximum zones. In the Gironde estuary, the large SPM concentrations associated with high POC:Chl $a$ ratio indicate strong hydrodynamic and sedimentary processes (deposition, resuspension) in the upstream estuary (especially pk30 and pk52). In this area, the high turbidity of the estuary likely leads to light limitation for phytoplankton growth. Turbidity decreases along the estuary (associated with the increase of salinities) partly due to a dilution of the particles allowing phytoplankton production in the upstream area. 
A. Inculding Gironde estuary, concentrations of POC sources Adjusted $\mathrm{R}^{2}: 0,65$

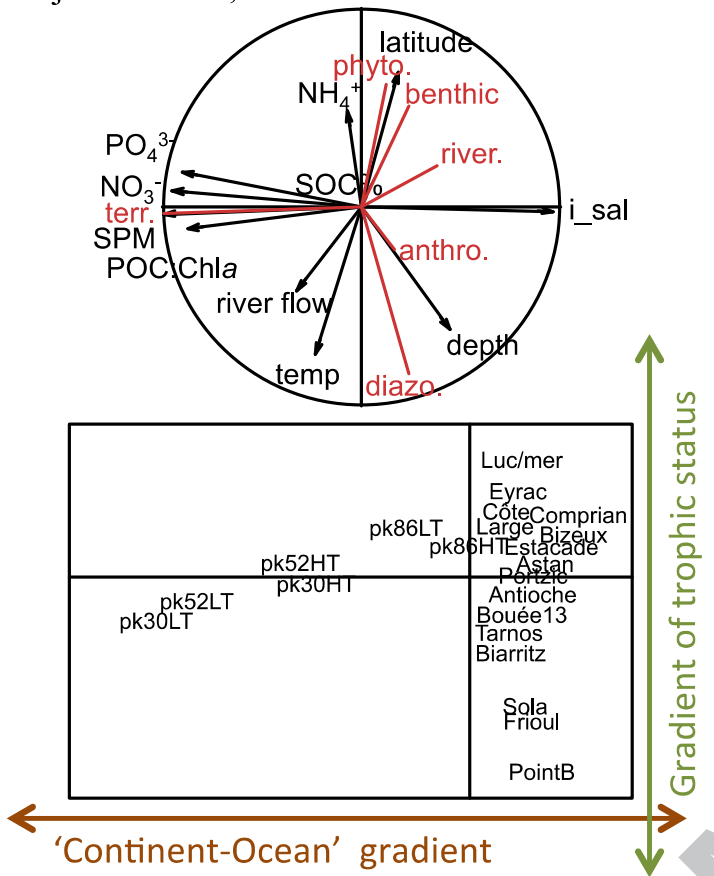

C. Marine stations only, concentrations of POC sources

Adjusted $\mathrm{R}^{2}: 0,55$

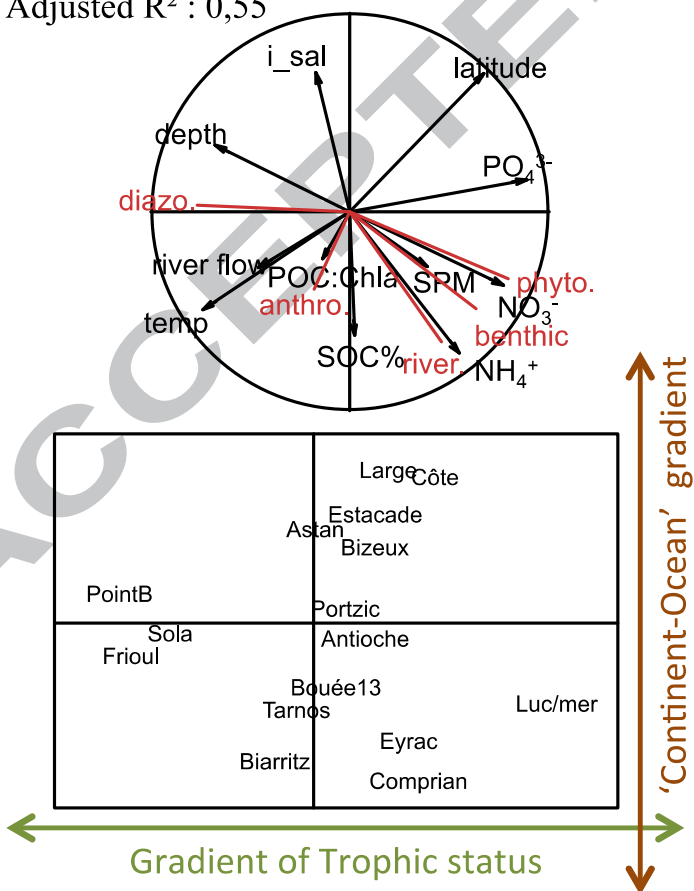

B. Including Gironde estuary, proportions of POC sources Adjusted $\mathrm{R}^{2}: 0,67$

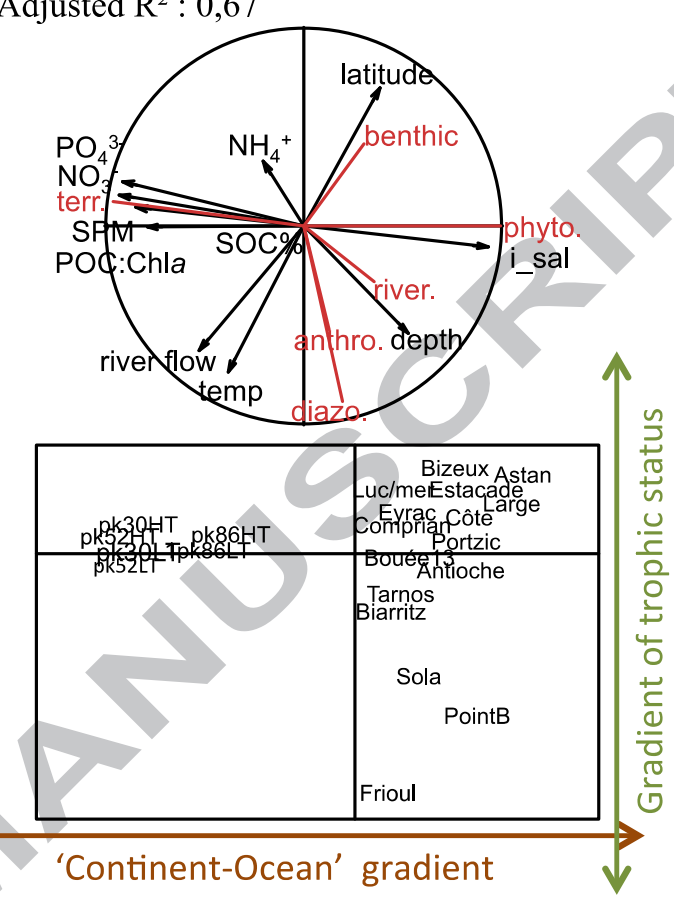

D. Marine stations only, proportions of POC sources

Adjusted R $\mathrm{R}^{2}$ : 0,47

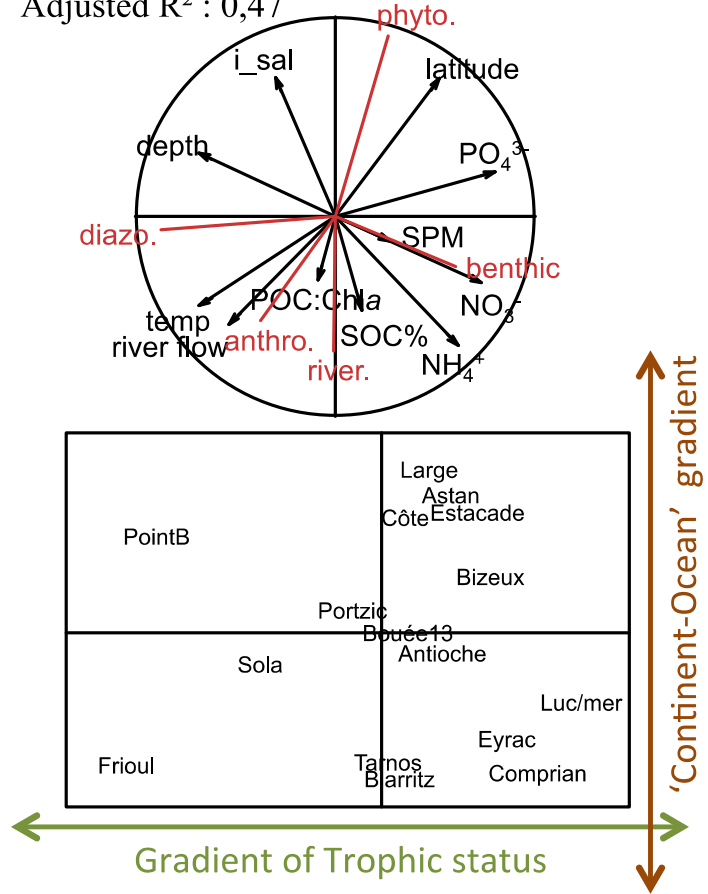

Figure 6: Redundancy analyses (correlation circles and plots of the samples scores) at multi-systems scale. Mean annual values of POC composition were used. A and B: including the Gironde estuary; C and D: without the Gironde estuary; A and C: performed on concentration of POC source; B and D performed on proportion of POc source. i_sal : salinity index (see 2.4.1); SPM : suspended particulate 
matter; temp : temperature; phyto. : phytoplankton; diazo. : diazotrophs; anthro. : anthropogenic POC; river. : river POC; terr. : terrestrial POC; benthic : benthic POC.

A similar 'Continent-Ocean' gradient is observed on the RDA Fig. 6 (C and D), which considers only the marine stations. It highlights the opposition between phytoplankton POC vs river and anthropogenic POC within the stations of Atlantic Ocean and English Channel. The stations of Côte, Large, Estacade and Astan are largely dominated by phytoplankton (>90\%) as opposed to other stations characterized by higher river and/or anthropogenic contributions (up to 25\% of both sources for Biarritz). Interestingly, Mediterranean stations are also distributed according this gradient (Fig. 6D). PointB, where POC is characterized by $83 \%$ phytoplankton and no POC is from riverine nor anthropogenic origin, is opposed to Frioul which exhibit less phytoplankton POC (71\%) and a non-negligible proportion of river and anthropogenic POC (7\% and 6\% respectively). Phytoplankton POC is associated with higher salinities whereas contribution of river and/or anthropogenic POC is associated to low salinities, high river flows and a high percentage of soil organic carbon of the watershed. These variables indicate a gradient driven by hydrodynamic processes (e.g. river flows, terrestrial runoffs).

Many studies report the dominance of phytoplankton in various marine-dominated coastal systems i.e. out of estuaries and river plumes (Berto et al., 2013; Cresson et al., 2012; Miller et al., 2013; Savoye et al., 2003; Tesi et al., 2007). Similarly, Côte, Large, Estacade and Astan present the largest contribution of phytoplankton and are the least impacted by river inputs, with no (Estacade, Astan) to 7\% (Côte) of river POC contribution. In contrast, the other stations exhibited a large contribution of river or anthropogenic POC. The proximity of the stations to the nearby rivers characterized by high river flows (Table 1) explains, for example, at Antioche (Charente and Gironde), Luc/mer (Seine and Orne) or Tarnos and Biarritz (Adour), the large contribution of river POC (19\%, 9\%, 15\% and 20\% respectively) or anthropogenic POC (Tarnos 6\% and Biarritz 5\%). Similar conclusions have already been made for other systems (Black Sea coastal waters, Bănaru et al. (2007); Winyah Bay in South Carolina, Goñi et al. (2009)) highlighting the importance of hydrodynamic processes in river POC contribution (Bourrin et al., 2008; Tesi et al., 2007). Also, the association of SOC content of watersheds with river and anthropogenic POC indicated a contribution of water runoff in hydrodynamic forcing. Other studies already demonstrate that soil derived organic matter (e.g. agricultural soil) can be introduced into the river and estuary by terrestrial runoff and is increased by extreme precipitation (Kaiser et al., 2014).

The second gradient observed is a gradient of trophic status illustrated on the axis2 of the two RDAs including the estuary (Figs. 6, A and B) and on the axis1 for the two other RDAs (Fig. 6, C and D). It opposes Mediterranean stations with the other marine stations. The contribution of diazotrophs is associated with high temperature and low nutrient concentrations $\left(\mathrm{PO}_{4}^{3-}, \mathrm{NO}_{3}{ }^{-}\right.$and $\mathrm{NH}_{4}{ }^{+}$; especially observable on the RDAs without Gironde, Fig. 6, C and D). These low nutrient concentrations associated to diazotrophs POC indicate that nutrient availability is the main forcing controlling the 
contribution of this source. Indeed, due to the oligotrophic nature of the Mediterranean Sea, 'classical' primary production linked to nitrogen uptake may be limited (Moutin and Raimbault, 2002). These peculiar conditions promote atmospheric $\mathrm{N}_{2}$-fixation by autotrophic organisms leading to a significant source of new nitrogen (Kerhervé et al., 2001; Rahav et al., 2013). Also, in some studies, nutrients have been identified as the main controlling factor of $\mathrm{N}_{2}$-fixation in oligotrophic waters of the Mediterranean (Ridame et al., 2011; Sandroni et al., 2007). By opposition, benthic POC is associated with high nutrient concentrations and is opposed to increasing depths of the water column (Fig. 6, C and D). These variables indicate the meso- to eutrophy of these systems mainly driven by the generally shallow depth of the water column of most of the stations. The influence of the benthic compartment to POM composition is thus greater due to the proximity with this source, and is negligible at Mediterranean stations due to their greater depths (Table 1). Also, high $\mathrm{NH}_{4}{ }^{+}$concentration takes part in remineralization processes and may indicate sediment resuspension (Gruber, 2008; Legendre and Rassoulzadegan, 1995; Pather et al., 2014; Spagnoli and Bergamini, 1997).

The use of RDAs allowed objectively identifying gradients of ecosystem functioning and environmental forcings at a large space scale. It revealed two main gradients: a continent-ocean gradient, with higher contributions of continental and benthic POC close to the continent and a higher contribution of phytoplankton POC away from the continent, and a gradient of trophic status with diazotroph contribution in oligotrophic systems. It also revealed the main forcings of POC composition: 1) hydrodynamics and sedimentary dynamics, 2) nutrient availability and 3) the geomorphology of the systems (depth of the water column).

\subsection{Seasonality and local forcings}

Redundancy Analyses (RDA) have also been performed for each station in order to determine which forcings may explain the relative contribution of sources to POC composition at local scale, taking into account the temporal variability that is stationspecific (section 3.2; Fig. 5).

The Gironde estuary is characterized by the large dominance and high seasonality of terrestrial POC (Fig. 3, Fig. 5) that peaks in autumn/winter (Fig. 4). Terrestrial material can be of two types: the terrestrial labile material coming from riparian POM mainly during high flood period, and the terrestrial refractory material, which is highly degraded and stored in the maximum turbidity zones for one to two years (Etcheber et al., 2007; Veyssy et al., 1998). The later represents the large majority of estuarine POC (ca. $89 \%$ of refractory material $v s$ ca. $3 \%$ of labile material). Terrestrial refractory POC is associated with high SPM concentrations and high POC:Chla ratio (Fig. 7). These variables indicate processes of resuspension/deposition of degraded POC related to sedimentary dynamics (see also 4.1). Terrestrial labile POC and phytoplankton POC are weakly represented on the correlation circle for both RDAs. In this system, POC distribution and composition are driven by the dynamics of the maximum turbidity zone, 
which is composed of refractory terrestrial POC: estuarine phytoplankton can only develop in the downstream estuary when and where the turbidity decreased, and freshwater phytoplankton and labile POC are only detected in the upstream estuary during high river flow (Liénart et al., 2017; Savoye et al., 2012; Etcheber et al., 2007). Other studies reach the same conclusions. Goñi et al. (2009) clearly demonstrate the role that physical processes play on the cycling of biogeochemical material (i.e. production, transport, degradation). More precisely, the authors found that resuspension processes of sediments are promoted by low river discharge and steady SW winds over the Winhay Bay (South Carolina, USA). Also, Zhang et al. (2007) highlighted the significance of resuspension/deposition processes in the determination of the nature of organic matter in SPM in Changjiang estuary (East China Sea). 
Cote

Adjusted R²: 0.10

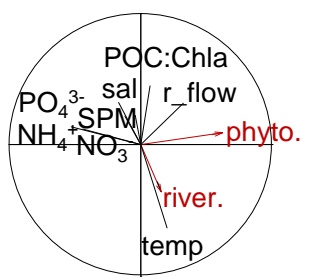

Luc

Adjusted $\mathrm{R}^{2}$ : 0.82 POC:Chla $\mathrm{NH}_{4}{ }^{+}$

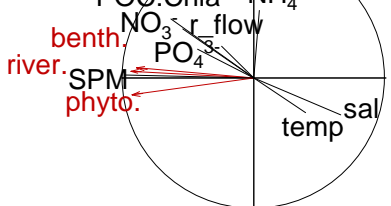

Estacade

Adjusted $\mathrm{R}^{2}$ : 0.28

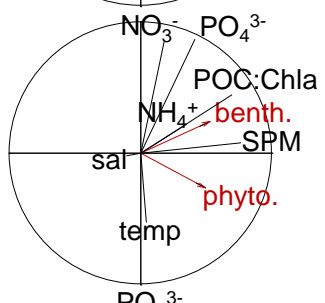

Portzic

Adjusted $\mathrm{R}^{2}: 0.50$

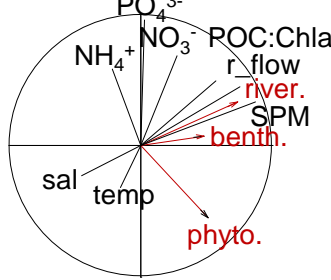

Comprian

Adjusted $\mathrm{R}^{2}: 0.30$

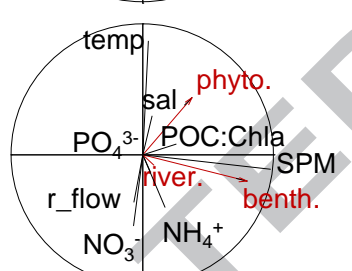

Bouée13

Adjusted $\mathrm{R}^{2}: 0.22$

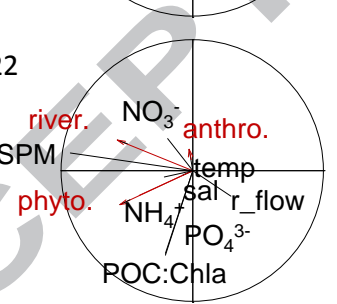

Biarritz

Adjusted $\mathrm{R}^{2}$ : 0.38

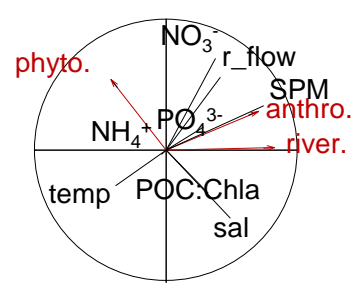

Large

Adjusted R²: 0.02

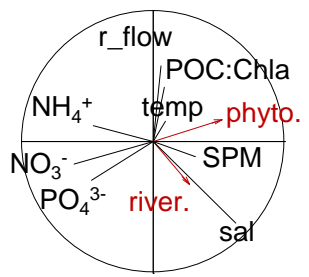

Bizeux

Adjusted $R^{2}: 0.58$

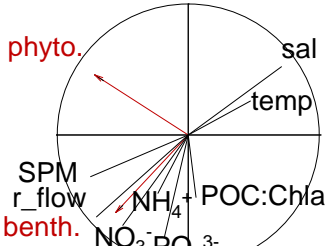

Astan

Adjusted $\mathrm{R}^{2}: 0.39$

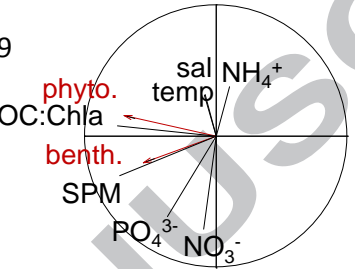

Antioche

Adjusted $\mathrm{R}^{2}$ : 0.31

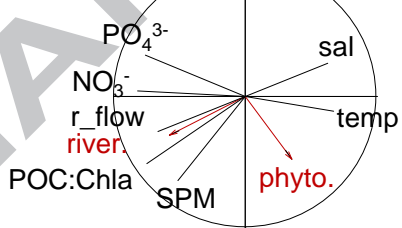

Eyrac

Adjusted $\mathrm{R}^{2}: 0.18$

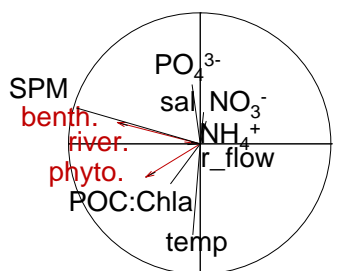

\section{Tarnos}

Adjusted $R^{2}$ : NA

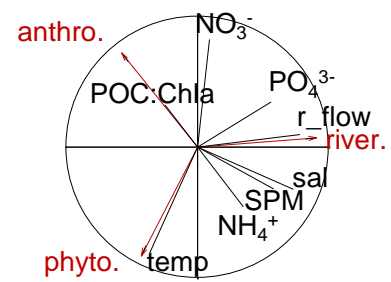

Sola

Adjusted $\mathrm{R}^{2}: 0.17$

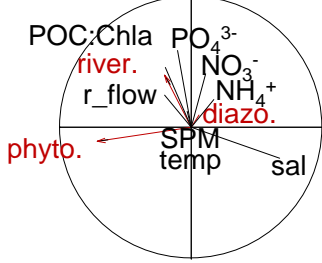



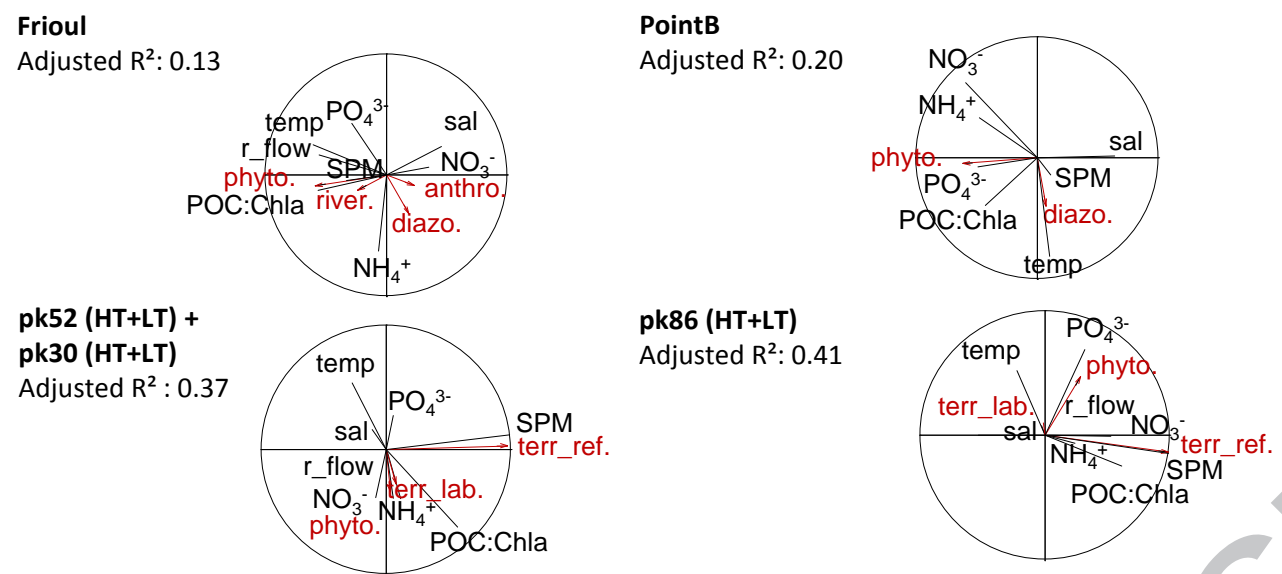

Figure 7: Redundancy analyses (correlation circles) at local scale. Date to date POC concentrations of each source were used. SPM: suspended particulate matter: temp: temperature; r_flow: river flow; sal: salinity; phyto. : phytoplankton, diazo. : diazotrophs, anthro. : anthropogenic POM, benthic : benthic POM, river. : river POM, terr_lab. : terrestrial labile POM; terr_ref.: terrestrial refractory POM. Adjusted $\mathrm{R}^{2}$ cannot be calculated for Tarnos due to the insufficient number of sampling dates.

For marine stations, phytoplankton POC presents a relatively high seasonality (0.65; Fig. 5) with increasing contribution during spring/summer (Fig. 4). The representation of phytoplankton POC on the correlation circle is almost always good (Fig. 7). However, when considering each station independently for the RDAs, variations in phytoplankton POC is not associated with a single environmental variable. In fact, phytoplankton growth is controlled by numerous environmental factors such as temperature, light, nutrient availability (Chen et al., 2000; Glé et al., 2008; Macedo et al., 2001) but is also largely influenced by hydrodynamics (Henriquez et al., 2007; Phlips et al., 2002; PujoPay et al., 2006). The optimal settings of these combined variables would then create favourable conditions for phytoplankton growth depending especially on site specificities. In a study investigating seasonal patterns of phytoplankton in 114 coastal systems of various types (including most of our study stations) Cloern and Jassby (2008) observed a high variability of seasonal patterns within geographic regions and even within ecosystems. The authors described a continuum of seasonal patterns and cited as examples of regional- and local-scale processes of phytoplankton variability in coastal systems, upwelling, river flow, wind driven resuspension, tidal mixing or nutrient inputs (cf. references therein). In a subsequent study including 84 of the previous systems (Cloern and Jassby, 2010), the same authors also described site-specificity namely anthropogenic disturbance, annual climatology and nutrient enrichment as driving patterns of phytoplankton variability. These results provide strong evidence that more than a few factors are driving phytoplankton seasonality at the land-sea-interface.

In Mediterranean systems, diazotrophs POC is weakly represented on the correlation circle and no clear forcing emerges from the analyses (Fig. 7), even if seasonality exists (0.57; Fig. 5; Fig. 4). Mediterranean waters experience a rapid nutrient limitation ( $\mathrm{N}$ and P) to phytoplankton growth, especially during the summer period when waters are stratified (Huertas et al., 2012). Thus, $\mathrm{N}_{2}$-fixation by cyanobacteria can contribute, for 
example, up to $55 \%$ of the new production in the north-western Mediterranean oligotrophic surface waters (Sandroni et al., 2007) and be maximum in stratified conditions (Bonnet et al., 2011). However, in coastal systems, nutrient limitation is circumvented by inputs from the adjacent compartments such as rivers (river flows), atmosphere (dry deposition) or even land (runoffs or sewage from anthropogenic origin). All the processes associated with nutrient inputs in coastal waters have their own seasonality. As an example, during summer when waters are stratified, external $\mathrm{N}$ inputs coming from atmospheric dry deposition may supply new nutrients for phytoplankton (de Fommervault et al., 2015) and enhance new production of phytoplankton origin to the detriment of diazotrophy. In addition, all these processes can overlap in space and/or time leading to a smoothed or irregular seasonality of primary production in Mediterranean systems. The highly dynamic and variable physical environment in terms of winds, currents, and waves that characterize the Mediterranean Sea (Durrieu de Madron et al., 2011; Ulses et al., 2008) forces nutrient inputs and thus, controls the balance between the two modes of pelagic primary production.

River POC contribution exhibits seasonal variations for most of the stations $(0.49$; Fig. 4; Fig. 5). It can be explained by different and associated forcings depending on the stations (Fig.7). First, river POC is associated with high river flows and a higher POC:Chla ratio and eventually high SPM as illustrated for Portzic, Antioche and Sola stations. This source is thus related to river hydrodynamics. This classical pattern of river POC contribution directly related to river flows has been largely described in literature (Fabres et al., 2008; Goñi et al., 2009; Lebreton et al., 2016; Sanchez-Vidal et al., 2013). However, river flow can be temporally uncoupled in time with the arrival of river POC at the studied station (e.g. Luc/mer Fig. 8). This phenomenon likely depends on the distance to the river mouth and/or to variability in current direction (Bourrin et al., 2008; Fabres et al., 2008). As an example, Kim et al. (2007) highlight the significant role of floods events (Têt river) in delivering terrestrial organic matter to the Mediterranean sea and Higueras et al. (2014) demonstrate in addition the importance of winds on the fluvial response in the same zone. Because local meteorological conditions force river hydrodynamics, their related seasonal patterns are tightly linked. Another process that may force river POC contribution is sediment deposition/resuspension. Indeed, river POM can sink, reach the sediment surface and then be resuspended. In this case, the river contribution is associated with a high POC:Chla ratio and increasing SPM concentration but uncoupled from river flow. In some systems, this process is dominant compared to direct river inputs (e.g. Biarritz, Bouée13), especially in shallow systems or when the tributary is distant. Sedimentary processes vary according to environmental conditions (Fain et al., 2007) and has been identified in previous studies as forcing POM composition (Goñi et al., 2009; Tesi et al., 2007). Finally, previous processes (also associated with a possible temporal shift) can occur simultaneously. In this case, the representation of river POC on the correlation circle is weak. This phenomenon is clearly illustrated at Eyrac and Comprian stations where the two processes have been identified 
(Dubois et al., 2012). A strong link emerges from hydrodynamics and sedimentary processes driving river POC: these forcings are closely tied up with local meteorological conditions and their related seasonal variations. They are heightened by extreme meteorological events such as storms (Kaiser et al., 2014) and floods (Higueras et al., 2014; Sanchez-Vidal et al., 2013).

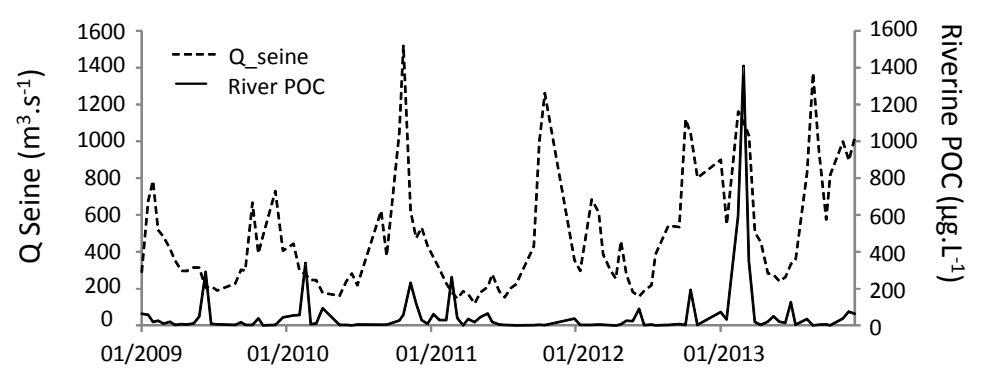

Figure 8: Time delay between river POC concentration at station Luc/mer and Seine river flow.

Benthic POC contribution exhibited a seasonal pattern for all stations (0.49; Fig. 5). It is usually characterized by a stronger contribution in autumn/winter (Fig. 4) even if some peaks also appear in other seasons, depending on the station. The contribution of this source is associated with high SPM concentrations (Fig. 7), indicating, similarly as for river POC, sedimentary resuspension processes (e.g. Comprian, Eyrac, Estacade, Astan). Many studies highlighted that benthic contribution to POM composition is mainly controlled by local sedimentary processes (deposition/resuspension) (Dubois et al., 2012; Schaal et al., 2009) which are influenced by meteorological conditions (winds, storms) and tidal currents (de Jonge and van Beusekom, 1995; Hochard et al., 2012; Lucas et al., 2000). Thus, the increase of winds and waves that occurs typically during winter in temperate systems, explain the increase in benthic POC during this season. Similar patterns of benthic influence have been demonstrated in the literature (Gao et al., 2014; Hill and McQuaid, 2008; Malet et al., 2008). Also, secondary peaks of benthic contribution are driven by the same process and can be explained by differences in macrophyte lifecycles leading to different periods of senescence and fragmentation (Leclerc et al., 2013).

Finally, anthropogenic source exhibit no clear seasonal pattern (0.26; Fig. 4; Fig. 5) and no forcing can be determined from the present analysis (Fig. 7). Multiple processes may locally force the contribution of this source and especially forcings linked to sewage water treatment plants (e.g. type of effluent) or to seasonal variations in tourism pressure (Berto et al., 2013). Also, the fate of treated effluents in coastal water depends on many local physical (Pradal and Millet, 2006), chemical and biological processes such 
as particles transportation, dilution or even the transfer to the planktonic food web (Bănaru et al., 2014) that are likely to be system specific.

Seasonal patterns in source contributions are likely related to the specificity of each station. However, the processes driving seasonal variations in POC concentrations of the sources are similar between stations. Hydrodynamics and sedimentary processes are driving terrestrial POC in the Gironde estuary. Similarly for the other stations, hydrodynamics and sedimentary processes also force river POC and benthic POC. River flows can also force river POC indirectly through deposition/resuspension processes. Anthropogenic POC is likely driven by multiple 'human-dependent' forcings associated with local currents and specific to each station. Finally, due to the numerous forcings to primary production, no clear association between phytoplankton and diazotroph POC and environmental variables could be reached from the present analyses. All the abovecited forcings are tightly linked to climate that also force most of the source contributions.

\subsection{Toward a typology of systems}

A typology of systems based on POC composition, dynamics and temporal variability was tested using regionalization method. This analysis allows to determine firstly groups of stations and secondly probabilities of membership for each station to each group (Fig. 9). The analysis has been performed on concentration (Fig. 9A) and proportion (Fig. 9B) of POM sources.

Overall, mean POM composition, more than the seasonality of POM composition, seems to be the main driver of the typology of systems (Fig. 9). A first group (Group I) gathers the three stations of the Gironde estuary. A second one (Group II) gathers the three stations of the Mediterranean façade. The last groups (Groups III and IV) are composed of all the other stations from English Channel and Atlantic Ocean but their distribution within the two groups varies depending on the considered dataset (concentration or proportion of POM sources). Some stations exhibit a strong belonging to a single group whereas others show a gradient of belonging to different groups.

Terrestrial versus phytoplankton predominance in terms of POC concentration and proportion discriminates estuarine stations (Group I) from the marine stations (Fig. 9, A and B), similarly to the Continent-Ocean gradient described in 4.1 (Fig. 6). Almost all estuarine stations belong to more than $90 \%$ to the Group I (Fig. 9, A and B). The only exception is observed for station pk86 at high tide (concentration dataset; Fig. 9A). It only belongs at ca. $30 \%$ to Group I due to its mean total POC concentration (ca. $800 \mu \mathrm{g} . \mathrm{L}^{-1}$ ) that is 3.5 to 10 times lower than for the other estuarine stations and for pk86LT (Fig. 3). The index of seasonality for the estuarine stations range from 0.45 to 0.69 and this group is characterized by a homogeneous composition of POM over the annual cycle. As it is well known, the Gironde estuary exhibits a POM composition dominated by terrestrial refractory material (see 4.1). In addition, its high SPM contents limits phytoplankton growth due to low light penetration (Middelburg and Herman, 
2007; Savoye et al., 2012). By opposition, phytoplankton is known to be the 'core contributor' to POM composition in coastal marine systems (Cresson et al., 2012; Lebreton et al., 2016; Lowe et al., 2014).

\section{A. Concentration of POM sources}

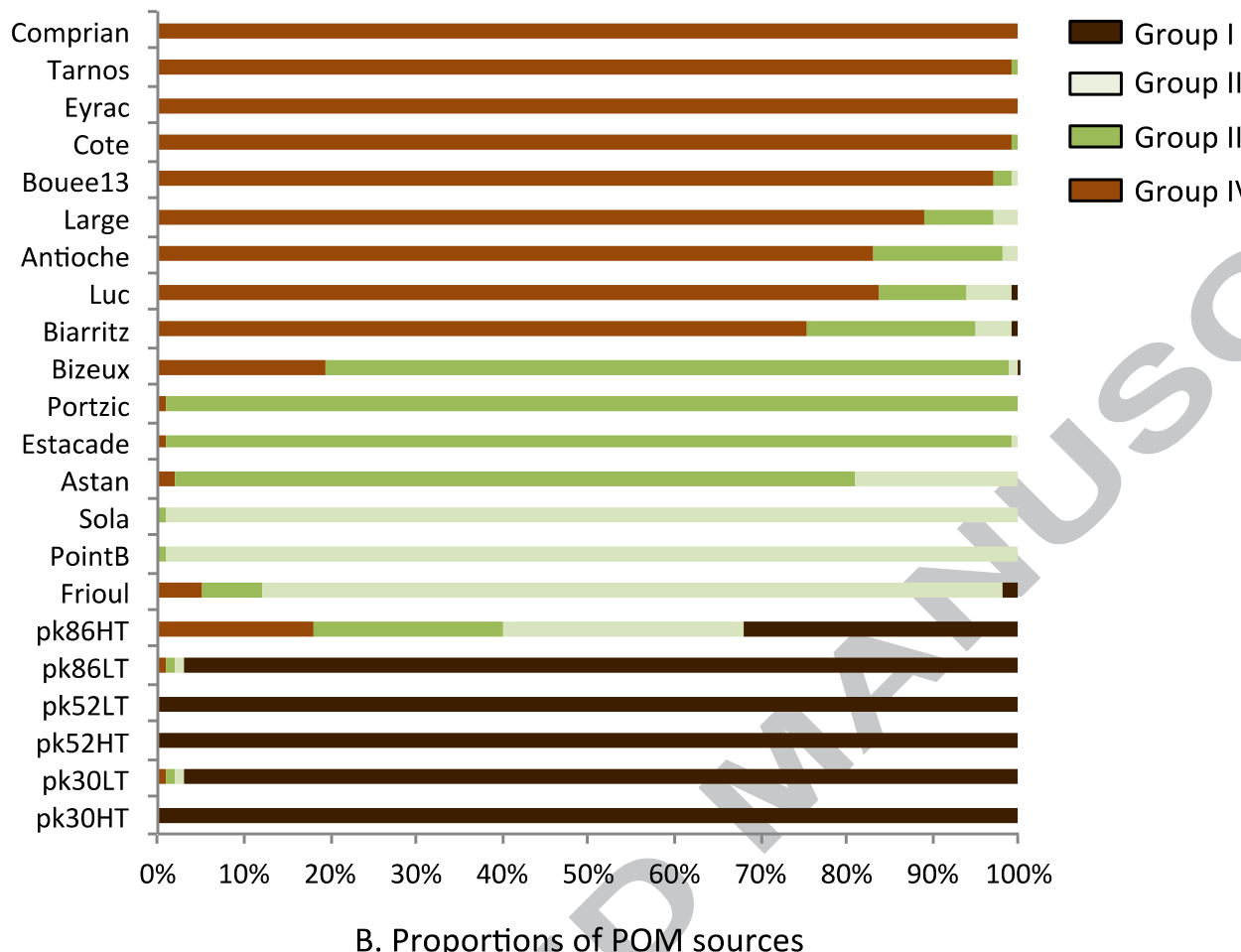

B. Proportions of POM sources

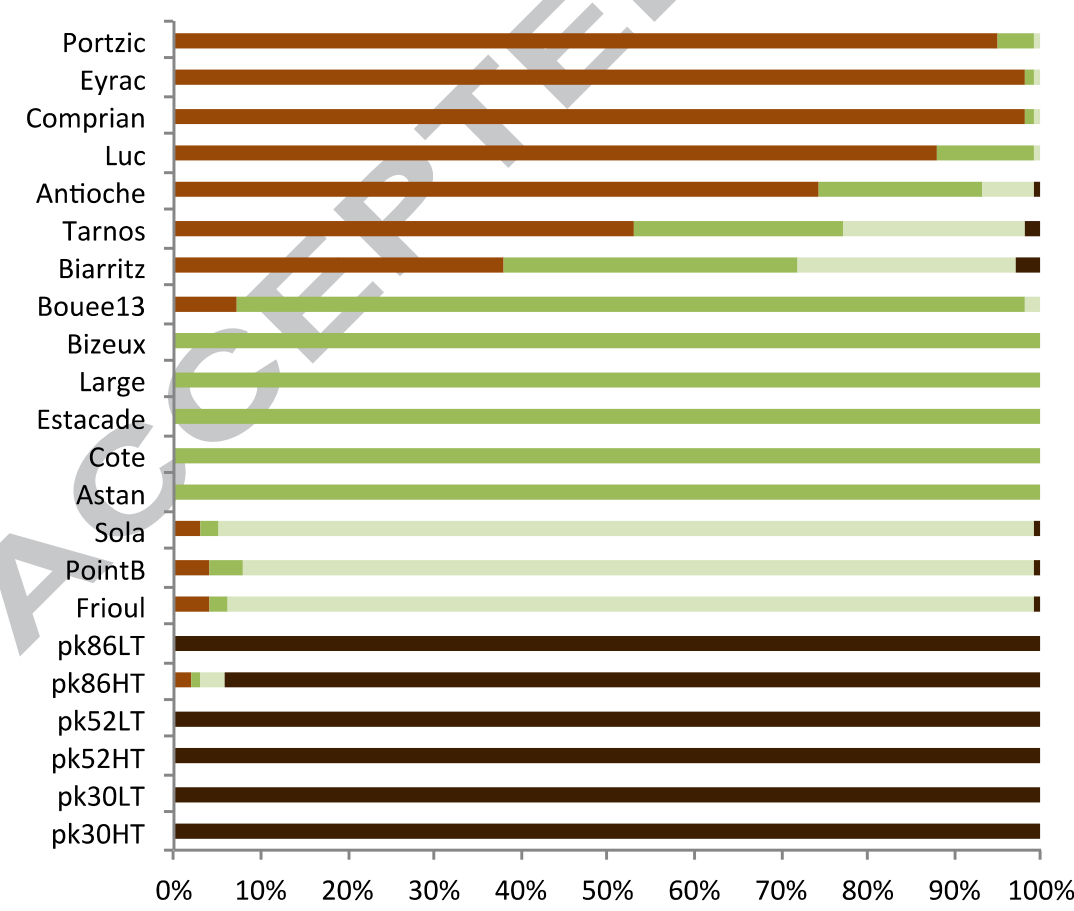

Figure 9: Typology of systems based on regionalization method for concentration (A) and proportion (B) of POC sources. For each station, the probability of belonging to each group is presented. 
Even if marine stations are characterized by large phytoplankton dominance they can be classified within three groups. Group II combines Mediterranean stations (Fig. 9, A and B). Sola, PointB and Frioul belong from 85 to $99 \%$ to this group. This discrimination is due to 1) the presence of diazotroph organisms specific to Mediterranean systems (similarly as the gradient of trophic status in 4.1, Fig. 6) and 2) the typically low POC concentrations for these three stations (60 to $120 \mu \mathrm{g} . \mathrm{L}^{-1}$ ) (Fig. 3). The seasonality index for the stations in this group vary from 0.56 to 0.61 and most of the sources are characterized by variable patterns of POM composition over the annual cycle. Diazotrophy is a well know phenomenon largely described in the oligotrophic Mediterranean waters (Kerhervé et al., 2001; Rahav et al., 2013) (see 4.1). Also, similarly to our POC concentrations, low phytoplankton biomass has been described for oligotrophic marine systems of the coastal Mediterranean Sea in a large-scale study conducted by Cloern and Jassby (2008).

The two last groups differ depending on the considered dataset. Based on POC concentrations (Fig. 9A) stations are classified as following: Group III gathers the stations of low POC concentration (ca. $150 \mu \mathrm{g} . \mathrm{L}^{-1}$ ). Stations Bizeux, Estacade, Astan and Portzic belong to this group at 75 to $95 \%$. Group IV gathers the stations of low POC concentration (ca. $330 \mu \mathrm{g} . \mathrm{L}^{-1}$ ). Stations Côte, Large, Luc/mer, Antioche, Comprian, Eyrac, Bouée13, Tarnos, and Biarritz belong to this group at 75 to $95 \%$. In addition, there is no or low influence of river POM for Group III (10 $\mu \mathrm{g} . \mathrm{L}^{-1}$ in Portzic) compared to Group IV (31 $\mu \mathrm{g} . \mathrm{L}^{-1}$ ). The index of seasonality ranges from 0.38 to 0.81 (average: 0.60 ) for the stations of Group III, and from 0.33 to 0.65 (average: 0.48) for stations of Group IV. Considering proportions (Fig. 9B) the discrimination of the two groups is made based on the relative contribution of phytoplankton versus other sources. Group III is characterized by stations exhibiting the largest contribution of phytoplankton ( $>89 \%$; Côte, Large, Estacade, Astan, Bizeux and Bouée13); they belong to this group at more than 90\%. Group IV gathers the other stations (Portzic, Eyrac, Comprian, Luc/mer, Antioche, Tarnos, and Biarritz), which are characterized by lower phytoplankton contribution and higher river (from 0 to $20 \%$ ) or benthic (from 0 to 18\%) contribution. Interestingly, belonging to the group for some of these stations is not always welldefined. Portzic, Eyrac, Comprian are located in the Atlantic Ocean and exhibit more than $95 \%$ of belonging to Group IV whereas Luc/mer, which is located in the English Channel, belong at $88 \%$ to this Group. All these stations are characterized by the largest contribution of benthic (8 to 19\%) and river source (8 to 14\%). Antioche belong at $74 \%$ to Group IV, probably due to its high contribution of river material (19\%), and at $18 \%$ to the Group III, probably due to its largest phytoplankton contribution (81\%). Finally, Tarnos and Biarritz belong in a shared way to the Groups IV (53 and 38\%, respectively) and III (24 and 34\%, respectively). This pattern is likely due to the large proportion of river material contributing to the POM composition of both sites (Tarnos $15 \%$ and Biarritz 20\%) but also to anthropogenic contribution (Tarnos 6\% and Biarritz 5\%). Indeed, the regionalization method is based on similarities between stations and within Group III, Bouée13 is also characterized by similar anthropogenic contribution (6\%). 
The index of seasonality ranges from 0.38 to 0.69 (average: 0.53 ) for Group III and from 0.33 to 0.81 (average: 0.51 ) for Group IV. This partition of the stations between Group III and IV is similar than the third gradient described in 4.1 (gradient of phytoplankton versus river/anthropogenic POC).

Seasonality seems to play a minor role in the repartition of the stations within the groups. Mean seasonality index is similar among groups: 0.55 for Group I (Gironde estuary), 0.59 for Group II (Mediterranean stations) and, based on proportion data sets, 0.53 for Group III (Côte, Large, Estacade, Astan and Bouée13) and 0.51 for Group IV. However, based on concentrations, seasonality index of Group III and IV are more contrasted: 0.60 (Group III, lower POC concentrations) versus 0.48 (Group IV, higher POC concentrations). The present study reveals that seasonality exists for most of the sources but is likely station-specific (see 4.2). Especially, systems dominated by phytoplankton are subject to variations in seasonal pattern for this source linked to sitespecificity (differences in anthropogenic disturbance, annual climatology and nutrient enrichment) (Cloern and Jassby, 2010).

Finally, even if large-scale typology discriminates stations mainly based on mean POM composition, forcings influencing source contribution are different for each group. As previously described (Fig. 6, A and B) and 4.2 (Fig. 7), hydrodynamics and sedimentary processes are the major environmental forcings to the composition of POM in the Gironde estuary (Group I). Contrarily, phytoplankton in marine stations is essentially driven by numerous processes including nutrient availability which depends on station specificity. The Group II with Mediterranean stations is mainly driven by the differences in nutrient concentrations and temperature (Fig. $6 \mathrm{~A}, \mathrm{~B}, \mathrm{D}$ ) specific to the climate of this region. Finally, the discrimination of stations within Group III and IV can also be explained by their associated forcings. Group IV is characterized by a largest contribution of river/benthic source essentially driven by hydrodynamics (i.e. river inputs) and sedimentary processes (i.e. resuspension). However, the gradient of belonging observed for some stations illustrates that processes leading to the composition of POM are also station-dependent. As also previously explained (Fig. 7), river or anthropogenic POM contributions are likely driven by more than one forcing and are strongly related to site specificities.

Processes leading to POM composition and dynamics are thus significant elements to consider in order to understand the functioning of these systems.

\section{Summary and prospects}

The originality of the present study lies in 1) the large spatial scale of the study that covers a panel of systems distributed over a gradient of environmental characteristics and forcings, 2) the consideration of seasonal and inter-annual variability of POM composition that allows to tend toward a 'typical' functioning of each studied system, and 3) the use of multivariate analysis. The latter, still uncommon in biogeochemistry, has the advantage of establishing a statistical link between forcings and POM 
composition and helps to gain more objectively insights into forcings. The method used in this study has been shown to effectively identify forcings at local but also multisystem scales, highlighting the possibility of extrapolating the general approach to other types of systems.

Because POM acts as a key link in the transfer of organic matter between continent and ocean, the identification of the processes leading to POM composition and dynamics is thus of high importance for a better understanding of systems functioning. The present study provides several insights on the different forcings to POM composition and dynamics in coastal systems at local and multi-system scales.

First, at large scale, two main gradients of POC composition have been identified: 1) a 'Continent-Ocean' gradient associated to hydrodynamics and sedimentary processes and 2) a gradient of trophic status related to diazotrophy and nutrient availability. Second, seasonality in POC composition appears to be station-specific, and the dynamics of POM composition in temperate coastal systems essentially results from the interaction between multiple forcings acting most of the time simultaneously. However, multivariate analysis reveals major processes driving seasonal variations of POC composition in surface water: 1) hydrodynamics and sedimentary processes have been identified as driving the contribution of terrestrial POC in the studied estuary and of river POC in the other systems; 2) similarly, sedimentary dynamics and the depth of the water column drives the contribution of benthic POC; 3) no main forcing to the contribution of phytoplankton POC has been identified; this is likely due to the multiplicity of environmental forcings (temperature, light and nutrient availability, etc.) that drive phytoplankton production and whose seasonality can deeply differ. Third, four types of systems, characterized by their mean POC composition and its associated forcings, were highlighted: 1) the estuarine stations where POC composition is dominated by terrestrial POM and driven by the hydrodynamics and sedimentary processes, 2) the oligotrophic systems, characterized by the contribution of diazotrophs due to low nutrient availability, and the marine meso/eutroph systems whose POC composition is either 3) deeply dominated by phytoplankton or 4) dominated by phytoplankton but where the contribution of continental and benthic POC is not negligible and is driven by the hydrodynamics, the sedimentary processes and the height of the water column. Seasonality seems to play a minor role in the definition of the system typology discrimination.

The multiplicity of driving factors and their related temporal and spatial variability at the land-sea interface show the difficulty of generalizing the dynamics of POM composition from local to global scale. This study shows the value in investigating various spatial and temporal scales to accurately portray land-ocean connectivity. Global climate change highly affects processes driving land-ocean POC export (i.e. precipitation and evapotranspiration and thus river discharge at decadal scales) (Bauer et al., 2013; Milliman et al., 2008). This will likely lead to modifications in quantity and seasonality of river POM inputs to coastal systems. Similarly, changes in river nutrient supply will 
likely induce changes in coastal primary production (Cotrim da Cunha et al., 2007). Such changes may modify the established typology of systems by acting on POM composition with potential implications for biogeochemical cycles and food webs. Hence, long-term monitoring of POM and environmental parameters in numerous systems is needed for a wide combination of climatic regions (i.e. from low to high latitudes) and system typology. This would help the better understanding of forcings at local and large scale.

\section{Acknowledgements}

This work was supported by the program PERMALA-LIGA, funded by the Aquitaine Regional Council, and by the French national program EC2CO-DRIL MOSLIT. A large part of the datasets was retrieved from the SOMLIT network (Service d'Observation en Milieu Littoral; http://somlit.epoc.u-bordeaux1.fr/fr), river flows were obtained thanks to BanqueHydro (http://www.hydro.eaufrance.fr/), l'Agence de l'Eau RhôneMediterrannée-Corse (http://eaurmc.fr), the Agence de l'Eau Adour-Garonne (http://adour-garonne.eaufrance.fr) and Compagnie Nationale du Rhône (http://www.cnr.tm.fr). Authors thanks E. Aksoy and collegues for the data of SOC\% and helping to perform the computations on our watersheds, B. Sautour, P.I. of the SOMLIT and the crewmembers of R/V Sépia II, Marphysa, Neomysis, l’Estran, Côtes de la Manche, Planula IV, Néréis II, Antedon II, Sagitta II and Téthys II.

\section{References}

Aksoy, E., Yigini, Y., Montanarella, L., 2016. Combining soil databases for topsoil organic carbon mapping in Europe. PLoS One 11, e0152098. doi:10.1371/journal.pone.0152098

Alpine, A., Cloern, J., 1988. Phytoplankton growth rates in a light-limited environment, San Francisco Bay. Mar. Ecol. Prog. Ser. 44, 167-173. doi:10.3354/meps044167

Bănaru, D., Carlotti, F., Barani, A., Grégori, G., Neffati, N., Harmelin-Vivien, M., 2014. Seasonal variation of stable isotope ratios of size-fractionated zooplankton in the Bay of Marseille (NW Mediterranean Sea). J. Plankton Res. 36, 145-156. doi:10.1093/plankt/fbt083

Bănaru, D., Harmelin-Vivien, M., Gomoiu, M.-T., Onciu, T.-M., 2007. Influence of the Danube River inputs on $\mathrm{C}$ and $\mathrm{N}$ stable isotope ratios of the Romanian coastal waters and sediment (Black Sea). Mar. Pollut. Bull. 54, 1385-1394. doi:10.1016/j.marpolbul.2007.05.022

Bauer, J.E., Cai, W.-J., Raymond, P.A., Bianchi, T.S., Hopkinson, C.S., Regnier, P., 2013. The changing carbon cycle of the coastal ocean. Nature 504, 61-70. doi:10.1038/nature12857

Berto, D., Rampazzo, F., Noventa, S., Cacciatore, F., Gabellini, M., Bernardi Aubry, F., Girolimetto, A., Boscolo Brusà, R., 2013. Stable carbon and nitrogen isotope ratios as tools to evaluate the nature of particulate organic matter in the Venice lagoon. Estuar. Coast. Shelf Sci. 135, 66-76. doi:10.1016/j.ecss.2013.06.021 
Bonnet, S., Grosso, O., Moutin, T., 2011. Planktonic dinitrogen fixation along a longitudinal gradient across the Mediterranean Sea during the stratified period (BOUM cruise). Biogeosciences 8, 2257-2267. doi:10.5194/bg-8-2257-2011

Bourrin, F., Friend, P.L., Amos, C.L., Manca, E., Ulses, C., Palanques, A., Durrieu de Madron, X., Thompson, C.E.L., 2008. Sediment dispersal from a typical Mediterranean flood: The Têt River, Gulf of Lions. Cont. Shelf Res. 28, 1895-1910. doi:10.1016/j.csr.2008.06.005

Brocard, D., Gillet, F., Legendre, P., 2011. Numerical Ecology with R (Use R!). SpringerVerlag New York. doi:10.1007/978-1-4419-7976-6

Chen, X., Lohrenz, S.E., Wiesenburg, D.A, 2000. Distribution and controlling mechanisms of primary production on the Louisiana - Texas continental shelf. J. Mar. Syst. 25, 179-207. doi:10.1016/S0924-7963(00)00014-2

Cloern, J.E., 1996. Phytoplankton bloom dynamics in coastal ecosystems: a review with some general lessons from sustained investigation of San Fransisco Bay, California. Rev. Geophys. 127-168. doi:10.1029/96RG00986

Cloern, J.E., Jassby, A.D., 2010. Patterns and scales of phytoplankton variability in estuarine-coastal ecosystems. Estuaries and Coasts 33, 230-241. doi:10.1007/s12237-009-9195-3

Cloern, J.E., Jassby, A.D., 2008. Complex seasonal patterns of primary producers at the land-sea interface. Ecol. Lett. 11,1294-1303. doi:10.1111/j.14610248.2008.01244.x

Cotrim da Cunha, L., Buitenhuis, E.T., Le Quéré, C., Giraud, X., Ludwig, W., 2007. Potential impact of changes in river nutrient supply on global ocean biogeochemistry. Global Biogeochem cy. 21, 1-15. doi:10.1029/2006GB002718

Cresson, P., Ruitton, S., Harmelin-Vivien, M., 2016. Feeding strategies of co-occuring suspension feeders in an oligotrophic environment. J. Food Webs. 6, 19-28. doi:10.1016/j.fooweb.2015.12.002

Cresson, P., Ruitton, S., Fontaine, M.F., Harmelin-Vivien, M., 2012. Spatio-temporal variation of suspended and sedimentary organic matter quality in the Bay of Marseilles (NW Mediterranean) assessed by biochemical and isotopic analyses. Mar. Pollut. Bull. 64, 1112-1121. doi:10.1016/j.marpolbul.2012.04.003

Dalu, T., Richoux, N.B., Froneman, P.W., 2016. Nature and source of suspended particulate matter and detritus along an austral temperate river-estuary continuum, assessed using stable isotope analysis. Hydrobiologia 767, 95-110. doi:10.1007/s10750-015-2480-1

Darnaude, A.M., Salen-Picard, C., Harmelin-Vivien, M.L., 2004. Depth variation in terrestrial particulate organic matter exploitation by marine coastal benthic communities off the Rhone River delta (NW Mediterranean). Mar. Ecol. Prog. Ser. 275, 47-57. doi:10.3354/meps275047

David, V., Ryckaert, M., Karpytchev, M., Bacher, C., Arnaudeau, V., Vidal, N., Maurer, D., Niquil, N., 2012. Spatial and long-term changes in the functional and structural 
phytoplankton communities along the French Atlantic coast. Estuar. Coast. Shelf Sci. 108, 37-51. doi:10.1016/j.ecss.2012.02.017

David, V., Sautour, B., Chardy, P., 2007. Successful colonization of the calanoid copepod Acartia tonsa in the oligo-mesohaline area of the Gironde estuary (SW France) Natural or anthropogenic forcing? Estuar. Coast. Shelf Sci. 71, 429-442. doi:10.1016/j.ecss.2006.08.018

de Fommervault, O.P., Migon, C., Dufour, A., D’Ortenzio, F., Kessouri, F., Raimbault, P., Garcia, N., Lagadec, V., 2015. Atmospheric input of inorganic nitrogen and phosphorus to the Ligurian Sea: Data from the Cap Ferrat coastal time-series station. Deep Sea Res. Part I Oceanogr. Res. Pap. 106, 116-125. doi:10.1016/j.dsr.2015.08.010

de Jonge, V.N., van Beusekom, J.E.E., 1995. Wind- and tide-induced resuspension of sediment and microphytobenthos from tidal flats in the Ems estuary. Limnol. Oceanogr. 40, 776-778. doi:10.4319/lo.1995.40.4.0776

Dodds, W.K., 1993. What controls levels of dissolved phosphate and ammonium in surface waters? Aquat. Sci. 55, 132-142. doi:10.1007/BF00877441

Dubois, S., Colombo, F., 2014. How picky can you be? Temporal variations in trophic niches of co-occuring suspension-feeding species. J. Food Webs. 1(1-4), 1-9. doi:10.1016/j.fooweb.2014.07.001

Dubois, S., Blanchet, H., Garcia, A., Massé, M., Galois, R., Grémare, A., Charlier, K., Guillou, G., Richard, P., Savoye, N., 2014. Trophic resource use by macrozoobenthic primary consumers within a semi-enclosed coastal ecosystem: Stable isotope and fatty acid assessment. J. Sea Res. 88, 87-99. doi:10.1016/j.seares.2014.01.004

Dubois, S., Savoye, N., Grémare, A., Plus, M., Charlier, K., Beltoise, A., Blanchet, H., 2012. Origin and composition of sediment organic matter in a coastal semi-enclosed ecosystem: An elemental and isotopic study at the ecosystem space scale. J. Mar. Syst. 94, 64-73. doi:10.1016/j.jmarsys.2011.10.009

Durrieu de Madron, X., Guieu, C., Sempéré, R., Conan, P., Cossa, D., D’Ortenzio, F., Estournel, C., Gazeau, F., Rabouille, C., Stemmann, L., Bonnet, S., Diaz, F., Koubbi, P., Radakovitch, O., Babin, M., Baklouti, M., Bancon-Montigny, C., Belviso, S., Bensoussan, N., Bonsang, B., Bouloubassi, I., Brunet, C., Cadiou, J.F., Carlotti, F., Chami, M., Charmasson, S., Charrière, B., Dachs, J., Doxaran, D., Dutay, J.C., ElbazPoulichet, F., Eléaume, M., Eyrolles, F., Fernandez, C., Fowler, S., Francour, P., Gaertner, J.C., Galzin, R., Gasparini, S., Ghiglione, J.F., Gonzalez, J.L., Goyet, C., Guidi, L., Guizien, K., Heimbürger, L.E., Jacquet, S.H.M., Jeffrey, W.H., Joux, F., Le Hir, P., Leblanc, K., Lefèvre, D., Lejeusne, C., Lemé, R., Loÿe-Pilot, M.D., Mallet, M., Méjanelle, L., Mélin, F., Mellon, C., Mérigot, B., Merle, P.L., Migon, C., Miller, W.L., Mortier, L., Mostajir, B., Mousseau, L., Moutin, T., Para, J., Pérez, T., Petrenko, A., Poggiale, J.C., Prieur, L., Pujo-Pay, M., Pulido-Villena, Raimbault, P., Rees, A.P., Ridame, C., Rontani, J.F., Ruiz Pino, D., Sicre, M.A., Taillandier, V., Tamburini, C., Tanaka, T., TaupierLetage, I., Tedetti, M., Testor, P., Thébault, H., Thouvenin, B., Touratier, F., Tronczynski, J., Ulses, C., Van Wambeke, F., Vantrepotte, V., Vaz, S., Verney, R., 2011. Marine ecosystems' responses to climatic and anthropogenic forcings in the Mediterranean. Prog. Oceanogr. 91, 97-166. doi:10.1016/j.pocean.2011.02.003 
Etcheber, H., Taillez, A., Abril, G., Garnier, J., Servais, P., Moatar, F., Commarieu, M.V., 2007. Particulate organic carbon in the estuarine turbidity maxima of the Gironde, Loire and Seine estuaries: Origin and lability. Hydrobiologia 588, 245-259. doi:10.1007/s10750-007-0667-9

Eyre, B.D., Ferguson, A.J.P., 2006. Impact of a flood event on benthic and pelagic coupling in a sub-tropical east Australian estuary (Brunswick). Estuar. Coast. Shelf Sci. 66, 111-122. doi:10.1016/j.ecss.2005.08.008

Fabres, J., Tesi, T., Velez, J., Batista, F., Lee, C., Calafat, A., Heussner, S., Palanques, A., Miserocchi, S., 2008. Seasonal and event-controlled export of organic matter from the shelf towards the Gulf of Lions continental slope. Cont. Shelf Res. 28, 1971-1983. doi:10.1016/j.csr.2008.04.010

Fain, A.M. V, Ogston, A.S., Sternberg, R.W., 2007. Sediment transport event analysis on the western Adriatic continental shelf. Cont. Shelf Res. 27, 431-451. doi:10.1016/j.csr.2005.03.007

Falkowski, P.G., Barber, R.T., Smetacek, V., 1998. Biogeochemical controls and feedbacks on ocean primary production. Science 281, 200-206. doi:10.1126/science.281.5374.200

Field, C.B., Behrenfeld, M.J., Randerson, J.T., Falkowski, P., 1998. Primary Production of the Biosphere: Integrating Terrestrial and Oceanic Components. Science 281, 237240. doi:10.1126/science.281.5374.237

Gao, L., Li, D., Ishizaka, J., 2014. Stable isotope ratios of carbon and nitrogen in suspended organicmatter: Seasonal and spatial dynamics along the Changjiang (Yangtze River) transport pathway. J. Geophys. Res. Biogeosciences 119, 557-566. doi:10.1002/2013JG002433

Glé, C., Del Amo, Y., Sautour, B., Laborde, P., Chardy, P., 2008. Variability of nutrients and phytoplankton primary production in a shallow macrotidal coastal ecosystem (Arcachon Bay, France). Estuar. Coast. Shelf Sci. 76, 642-656. doi:10.1016/j.ecss.2007.07.043

Goberville, E., Beaugrand, G., Sautour, B., Tréguer, P., 2010. Climate-driven changes in coastal marine systems of western Europe. Mar. Ecol. Prog. Ser. 408, 129-147. doi:10.3354/meps08564

Goñi, M.A., Voulgaris, G., Kim, Y.H., 2009. Composition and fluxes of particulate organic matter in a temperate estuary (Winyah Bay, South Carolina, USA) under contrasting physical forcings. Estuar. Coast. Shelf Sci. 85, 273-291. doi:10.1016/j.ecss.2009.08.013

Gruber, N., 2008. The Marine Nitrogen Cycle, in: Nitrogen in the Marine Environment. Elsevier, pp. 1-50. doi:10.1016/B978-0-12-372522-6.00001-3

Harmelin-Vivien, M., Loizeau, V., Mellon, C., Beker, B., Arlhac, D., Bodiguel, X., Ferraton, F., Hermand, R., Philippon, X., Salen-Picard, C., 2008. Comparison of C and N stable isotope ratios between surface particulate organic matter and microphytoplankton in the Gulf of Lions (NW Mediterranean). Cont. Shelf Res. 28, 1911-1919. 
doi:10.1016/j.csr.2008.03.002

Henriquez, L.A., Daneri, G., Munoz, C.A., Montero, P., Veas, R., Palma, A.T., 2007. Primary production and phytoplanktonic biomass in shallow marine environments of central Chile: Effect of coastal geomorphology. Estuar. Coast. Shelf Sci. 73, 137-147. doi:10.1016/j.ecss.2006.12.013

Higueras, M., Kerhervé, P., Sanchez-vidal, A., Calafat, A., Ludwig, W., Verdoit-Jarraya, M., Heussner, S., Canals, M., 2014. Biogeochemical characterization of the riverine particulate organic matter transferred to the NW Mediterranean Sea. Biogeosciences 11, 157-172. doi:10.5194/bg-11-157-2014

Hill, J.M., McQuaid, C.D., 2008. $\delta^{13} \mathrm{C}$ and $\delta^{15} \mathrm{~N}$ biogeographic trends in rocky intertidal communities along the coast of South Africa: Evidence of strong environmental signatures. Estuar. Coast. Shelf Sci. 80, 261-268. doi:10.1016/j.ecss.2008.08.005

Hochard, S., Pinazo, C., Rochelle-Newall, E., Pringault, O., 2012. Benthic pelagic coupling in a shallow oligotrophic ecosystem: Importance of microphytobenthos and physical forcing. Ecol. Modell. 247, 307-318. doi:10.1016/j.ecolmodel.2012.07.038

Huertas, I.E., Ríos, A.F., García-Lafuente, J., Navarro, G., Makaoui, A., Snchez-Romn, A., Rodriguez-Galvez, S., Orbi, A., Ruíz, J., Pérez, F.F., 2012. Atlantic forcing of the Mediterranean oligotrophy. Global Biogeochem. Cycles 26, 1-9. doi:10.1029/2011GB004167

Kaiser, D., Unger, D., Qiu, G., 2014. Particulate organic matter dynamics in coastal systems of the northern Beibu Gulf. Cont. Shelf Res. 82, 99-118. doi:10.1016/j.csr.2014.04.006

Kerhervé, P., Minagawa, M., Heussner, S., Monaco, A., 2001. Stable isotopes $\left({ }^{13} \mathrm{C} /{ }^{12} \mathrm{C}\right.$ and ${ }^{15} \mathrm{~N} /{ }^{14} \mathrm{~N}$ ) in settling organic matter of the northwestern Mediterranean Sea: biogeochemical implications. Oceanol. Acta 24, S77-S85. doi:10.1016/S03991784(00)01111-7

Kim, J.H., Schouten, S., Bonnin, J., Buscail, R., Ludwig, W., Sinninghe Damsté, J.S., Bourrin, F., 2007. Origin and distribution of terrestrial organic matter in the NW Mediterranean (Gulf of Lions): Exploring the newly developed BIT index. Geochemistry, Geophys. Geosystems 7, 1593-1606. doi:10.1029/2006GC001306

Lebreton, B., Beseres, J., Blomberg, B., Palmer, T.A., Adams, L., 2016. Origin , composition and quality of suspended particulate organic matter in relation to freshwater in $\mathrm{fl}$ ow in a South Texas estuary. Estuar. , Coast. Shelf Sci. 170, 70-82. doi:10.1016/j.ecss.2015.12.024

Leclerc, J.C., Riera, P., Leroux, C., Lévèque, L., Davoult, D., 2013. Temporal variation in organic matter supply in kelp forests: Linking structure to trophic functioning. Mar. Ecol. Prog. Ser. 494, 87-105. doi:10.3354/meps10564

Legendre, P., Legendre, L.F., 1998. Numerical Ecology. Second English edition. Elsevier Science.

Legendre, L., Rassoulzadegan, F., 1995. Plankton and nurients dynamics in marine waters. Ophelia 41, 153-172. doi:10.1080/00785236.1995.10422042 
Liénart, C., Susperregui, N., Rouaud, V., Cavalheiro, J., David, V., Del Amo, Y., Duran, R., Lauga, B., Monperrus, M., Pigot, T., Bichon, S., Charlier, K., Savoye, N., 2016. Dynamics of particulate organic matter in a coastal system characterized by the occurrence of marine mucilage - A stable isotope study. J. Sea Res. 1-11. doi:10.1016/j.seares.2016.08.001

Liénart, C., Saoye, N., Bozec, Y., Breton, E., Conan, P., David, V., Feunteun, E., Grangeré, K., Kerhervé, P., Lebreton, B., Lefebvre, S., L'Helguen, S., Mousseau, L., Raimbault, P., Richard, P., Riera, P., Sauriau, P-G., Schaal, G., Aubert, F., Aubin, S., Bichon, S., Boinet, C., Bourasseau, L., Bréret, M., Caparros, J., Cariou, T., Charlier, K., Claquin, P., Cornille, V., Corre, A-M., Costes, L., Crispi, O., Crouvoisier, M., Czamanski, M., Del Amo, Y., Derriennic, H., Dindinaud, F., Durozier, M., Hanquiez, V., Nowaczyk, A., Devesa, J., Ferreira, S., Fornier, M., Garcia, F., Garcia, N., Geslin, S., Grossteffan, E., Gueux, A., Guillaudeau, J., Guillou, G., Joly, O., Lachaussée, N., Lafont, M., Lamoureux, J., Lecuyer, E., Lehodey, J-P., Lemeille, D., Leroux, C., Macé, E., Maria, E., Pineau, P., Petit, F., PujoPay, M., Rimelin-Maury, P., Sultan, E. (2017). Dynamics of particulate organic matter composition in coastal systems: a spatio-temporal study at multi-systems scale. Prog. Oceanogr. 156, 221-239. doi:10.1016/j.pocean.2017.03.001

Liu, K.K., Kao, S.J., Wen, L.S., Chen, K.L., 2007. Carbon and nitrogen isotopic compositions of particulate organic matter and biogeochemical processes in the eutrophic Danshuei Estuary in northern Taiwan. Sci. Total Environ. 382, 103-120. doi:10.1016/j.scitotenv.2007.04.019

Lowe, A.T., Galloway, A.W.E., Yeung, J.S., Dethier, M.N., Duggins, D.O., 2014. Broad sampling and diverse biomarkers allow characterization of nearshore particulate organic matter. Oikos 123,1341-1354. doi:10.1111/oik.01392

Lucas, C.H., Widdows, J., Brinsley, M.D., Salkeld, P.N., Herman, P.M.J., 2000. Benthicpelagic exchange of microalgae at a tidal flat. 1. Pigment analysis. Mar. Ecol. Prog. Ser. 196, 59-73. doi:10.3354/meps196059

Macedo, M.F., Duarte, P., Mendes, P., Ferreira, J.G., 2001. Annual variation of environmental variables phytoplankton species composition and photosynthetic parameters in a coastal lagoon. J. Plankton Res. 23, 719-732. doi:10.1093/plankt/23.7.719

Malet, N., Sauriau, P.G., Ryckaert, M., Malestroit, P., Guillou, G., 2008. Dynamics and sources of suspended particulate organic matter in the Marennes-Oléron oyster farming bay: Insights from stable isotopes and microalgae ecology. Estuar. Coast. Shelf Sci. 78, 576-586. doi:10.1016/j.ecss.2007.11.001

Middelburg, J.J., Herman, P.M.J., 2007. Organic matter processing in tidal estuaries. Mar. Chem. 106, 127-147. doi:10.1016/j.marchem.2006.02.007

Miller, R.J., Page, H.M., 2012. Kelp as a trophic resource for marine suspension feeders: A review of isotope-based evidence. Mar. Biol. 159, 1391-1402. doi:10.1007/s00227012-1929-2

Miller, R.J., Page, H.M., Brzezinski, M.A., 2013. $\delta^{13} \mathrm{C}$ and $\delta^{15} \mathrm{~N}$ of particulate organic matter in the Santa Barbara Channel: Drivers and implications for trophic inference. Mar. Ecol. Prog. Ser. 474, 53-66. doi:10.3354/meps10098 
Milliman, J.D., Farnsworth, K.L., Jones, P.D., Xu, K.H., Smith, L.C., 2008. Climatic and anthropogenic factors affecting river discharge to the global ocean, $1951-2000$. Global Planet Change 62, 187-194. doi:10.1016/j.gloplacha.2008.03.001

Modéran, J., Bouvais, P., David, V., Le Noc, S., Simon-Bouhet, B., Niquil, N., Miramand, P., Fichet, D., 2010. Zooplankton community structure in a highly turbid environment (Charente estuary, France): Spatio-temporal patterns and environmental control. Estuar. Coast. Shelf Sci. 88, 219-232. doi:10.1016/j.ecss.2010.04.002

Moutin, T., Raimbault, P., 2002. Primary production, carbon export and nutrients availability in wester and eastern Mediterrean Sea in early summer 1996 (MINOS cruise). J. Mar. Syst. 33-34, 273-288.

Ostrom, N.E., Macko, S.A., Deibel, D., Thompson, R.J., 1997. Seasonal variation in the stable carbon and nitrogen isotope biogeochemistry of a coastal cold ocean environment. Geochim. Cosmochim. Acta 61, 2929-2942. doi:10.1016/S00167037(97)00131-2

Pather, S., Pfister, C.A., Post, D.M., Altabet, M.A., 2014. Ammonium cycling in the rocky intertidal: Remineralization, removal, and retention. Limnol. Oceanogr. 59, 361-372. doi:10.4319/lo.2014.59.2.0361

Phlips, E.J., Badylak, S., Grosskopf, T., 2002. Factors affecting the abundance of phytoplankton in a restricted subtropical lagoon, the Indian River lagoon, Florida, USA. Estuar. Coast. Shelf Sci. 55, 385-402. doi:10.1006/ecss.2001.0912

Pradal, M.-A., Millet, B., 2006. Hétérogénéité spatiale du forçage du vent: fonctionnement des récifs artificiels et circulation des eaux dans la baie sud de Marseille. C.R. Biol. 329, 541-550. doi: 10.1016/j.crvi.2006.04.002

Pradhan, U.K., Wu, Y., Shirodkar, P.V., Zhang, J., Zhang, G., 2014. Sources and distribution of organic matter in thirty five tropical estuaries along the west coast of India-a preliminary assessment. Estuar. Coast. Shelf Sci. 151, 21-33.

doi:10.1016/j.ecss.2014.09.010

Pujo-Pay, M., Conan, P., Joux, F., Oriol, L., Naudin, J.J., Cauwet, G., 2006. Impact of phytoplankton and bacterial production on nutrient and DOM uptake in the Rhône River plume (NW Mediterranean). Mar. Ecol. Prog. Ser. 315, 43-54. doi:10.3354/meps315043

Rahav, E., Herut, B., Levi, A., Mulholland, M.R., Berman-Frank, I., 2013. Springtime contribution of dinitrogen fixation to primary production across the Mediterranean Sea. Ocean Sci. 9, 489-498. doi:10.5194/os-9-489-2013

Ridame, C., Le Moal, M., Guieu, C., Ternon, E., Biegala, I.C., L’Helguen, S., Pujo-Pay, M., 2011. Nutrient control of $\mathrm{N}_{2}$ fixation in the oligotrophic Mediterranean Sea and the impact of Saharan dust events. Biogeosciences 8, 2773-2783. doi:10.5194/bg-82773-2011

Sanchez-Vidal, A., Higueras, M., Martí, E., Liquete, C., Calafat, A., Kerhervé, P., Canals, M., 2013. Riverine transport of terrestrial organic matter to the North Catalan margin , NW Mediterranean Sea. Prog. Oceanogr. 118, 71-80. 
doi:10.1016/j.pocean.2013.07.020

Sandroni, V., Raimbault, P., Migon, C., Garcia, N., Gouze, E., 2007. Dry atmospheric deposition and diazotrophy as sources of new nitrogen to northwestern Mediterranean oligotrophic surface waters. Deep. Res. Part I Oceanogr. Res. Pap. 54, 1859-1870. doi:10.1016/j.dsr.2007.08.004

Sarma, V.V.S.S., Krishna, M.S., Prasad, V.R., Kumar, B.S.K., Naidu, S.A., Rao, G.D., Viswanadham, R., Sridevi, T., Kumar, P.P., Reddy, N.P.C., 2014. Distribution and sources of particulate organic matter in the Indian monsoonal estuaries during monsoon. J. Geophys. Res. Biogeosciences 2095-2111. doi:10.1002/2014JG002721.Received

Sato, T., Miyajima, T., Ogawa, H., Umezawa, Y., Koike, I., 2006. Temporal variability of stable carbon and nitrogen isotopic composition of size-fractionated particulate organic matter in the hypertrophic Sumida River Estuary of Tokyo Bay, Japan. Estuar. Coast. Shelf Sci. 68, 245-258. doi:10.1016/j.ecss.2006.02.007

Savoye, N., Aminot, A., Tréguer, P., Fontugne, M., Naulet, N., Kérouel, R., 2003. Dynamics of particulate organic matter $\delta^{15} \mathrm{~N}$ and $\delta^{13} \mathrm{C}$ during spring phytoplankton blooms in a macrotidal ecosystem (Bay of Seine , France). Mar. Ecol. Prog. Ser. 255, 27-41. doi:10.3354/meps255027

Savoye, N., David, V., Morisseau, F., Etcheber, H., Abril, G., Billy, I., Charlier, K., Oggian, G., Derriennic, H., Sautour, B., 2012. Origin and composition of particulate organic matter in a macrotidal turbid estuary: The Gironde Estuary, France. Estuar. Coast. Shelf Sci. 108, 16-28. doi:10.1016/j.ecss.2011.12.005

Schaal, G., Riera, P., Leroux, C., 2009. Trophic significance of the kelp Laminaria digitata (Lamour.) for the associated food web: a between-sites comparison. Estuar. Coast. Shelf Sci. 85, 565-572. doi:10.1016/j.ecss.2009.09.027

Souissi, S., Yahia-Kéfi, O.D., Yahia, M.N.D., 2000. Spatial characterization of nutrient dynamics in the Bay of Tunis (south-western Mediterranean) using multivariate analyses: consequences for phyto- and zooplankton distribution. J. Plankton Res. 22, 2039-2059. doi:10.1093/plankt/22.11.2039

Spagnoli, F., Bergamini, M.C., 1997. Water - sediment exchange of nutrients during early diagenesis and resuspension of anoxic sediments from the northern adriatic sea shelf. Water. Air. Soil Pollut. 99, 541-556. doi:10.1023/A:1018364111899

Tesi, T., Miserocchi, S., Goñi, M.A., Langone, L., Boldrin, A., Turchetto, M., 2007. Organic matter origin and distribution in suspended particulate materials and surficial sediments from the western Adriatic Sea (Italy). Estuar. Coast. Shelf Sci. 73, 431446. doi:10.1016/j.ecss.2007.02.008

Tortajada, S., David, V., Brahmia, A., Dupuy, C., Laniesse, T., Parinet, B., Pouget, F., Rousseau, F., Simon-Bouhet, B., Robin, F.X., 2011. Variability of fresh- and salt-water marshes characteristics on the west coast of France: A spatio-temporal assessment. Water Res. 45, 4152-4168. doi:10.1016/j.watres.2011.05.024

Ulses, C., Estournel, C., Durrieu de Madron, X., Palanques, A., 2008. Suspended sediment 
transport in the Gulf of Lions (NW Mediterranean): Impact of extreme storms and floods. Cont. Shelf Res. 28, 2048-2070. doi:10.1016/j.csr.2008.01.015

Veyssy, E., Etcheber, H., Lin, R.G., Buat-Menard, P., Maneux, E., 1998. Seasonal variation and origin of Particulate Organic Carbon in the lower Garonne River at La Reole (southwestern France). Hydrobiologia 391, 113-126.

doi:10.1023/A:1003520907962

Volkman, J., Tanoue, E., 2002. Chemical and biological studies of particulate organic matter in the ocean. J. Oceanogr. 58, 265-279. doi:10.1023/A:1015809708632

Zhang, J., Wu, Y., Jennerjahn, T.C., Ittekkot, V., He, Q., 2007. Distribution of organic matter in the Changjiang (Yangtze River) Estuary and their stable carbon and nitrogen isotopic ratios: Implications for source discrimination and sedimentary dynamics. Mar. Chem. 106, 111-126. doi:10.1016/j.marchem.2007.02.003 


\section{Highlights}

- Three littoral systems, eight embayments and one estuary were studied

- POC composition was related to 'Continent-Ocean' and trophic-status gradients

- Forcings were (sedimentary) hydrodynamics, water column depth, nutrient availability

- At local scale POC composition appears to be station-specific but still related to the above-mentioned forcings

- A typology of systems was drawn based on POM composition 